\title{
Sol-gel alumina coating of wired mesh packing
}

Mohamed Abdelraouf ${ }^{1}$, Josef Hegarty ${ }^{1}$, Allan Rennie ${ }^{1}$, Rémi Elizalde ${ }^{2}$, Neil Burns ${ }^{3}$, Louise Geekie $^{3}$, Vesna Najdanovic-Visak ${ }^{4 *}$ Farid Aiouache ${ }^{1^{*}}$

${ }^{1}$ Engineering Department, Faculty of Science and Technology, Lancaster University, Lancaster LA1 4YW, United Kingdom.

2 INP ENSIACET, 4 Allee Emile Monso-CS 44362,31030 Toulouse CEDEX-France

${ }^{3}$ Croft Filters Ltd, Taylor Business Park, Warrington WA3 6BL, United Kingdom.

${ }^{4}$ Chemical Engineering and Applied Chemistry (CEAC), Energy and Bioproducts Research Institute (EBRI), Aston University, Birmingham B4 7ET, United Kingdom.

*Corresponding authors: v.najdanovic@aston.ac.uk; f.aiouache@lancaster.ac.uk

\begin{abstract}
Wired mesh packings have seen increasing applications to multiphase processes in recent years. Despite the high surface area, open structure and thermal and chemical resistance, wired mesh packings have a complex geometry which hinders some chemical applications, including changes of surface properties through application of a uniformly adhesive coating. In this work, the sol-gel deposition method of alumina coating ceramics was investigated for the first time on stainless steel wired mesh by using Dixon rings as example. The kinetics of deposition during the hydrolysis and polycondensation was followed for a range of initial composition of the coating such as the ratios of $\mathrm{Al}_{2} \mathrm{O}_{3}$ to water, acid content,
\end{abstract}


polyethyleneimine binder content and the number of deposition cycles. Well-adhered alumina with a thickness up to $20 \mu \mathrm{m}$ was successfully deposited. The molar ratios of acid to alumina and alumina to water of 0.25 and 0.01 , respectively, $48 \mathrm{~h}$ of the aging time, $96 \mathrm{~h}$ of the mixing time and $2.1 \mathrm{~g} / \mathrm{L}$ of polyethyleneimine binder formed a free of cracks coating of controlled thickness alumina on the Dixon rings.

Keywords

Column packing, alumina ceramics coating, wired mesh coating, Dixon ring, sol-gel, stainless steel coating 


\section{Introduction}

The deposition of porous oxides, such as alumina ceramics $\left(\mathrm{Al}_{2} \mathrm{O}_{3}\right)$, on metallic packing serves an important role in the chemical industry [1]. It is attracting interest in applications for multiphase corrosion protection, radiation reflection [2], abrasion resistance [3], reactive processes as a solid catalyst carrier and hybrid reactive systems through process intensification strategies [4]. The methods of deposition of $\mathrm{Al}_{2} \mathrm{O}_{3}$ are multiple, depending on the applications, and include chemical vapour deposition (CVD) [5], physical vapour deposition (PVD) [6], plasma sputtering [7] and wash-coating [8,9]. These methods of coating metallic substrates remain onerous, particularly when they are intended to be used for applications at industrial-scale under controlled surface properties [10]. Meille et al. [11] showed that the reproduction of $\mathrm{Al}_{2} \mathrm{O}_{3}$ coating by combining several milling steps of coarse powders and wash-coating, was not straightforward in terms of achieving good surface adhesiveness. A study by Guglielmi [12] reviewed the values of metal coating via sol-gel techniques. The sol-gel method, which manufactures thin films of high purity at moderate temperature, is essentially waste-free and eliminates the use of coarse powders, favouring the potential for coating complex geometries. The method is recurringly cited as promising to produce cost-effective coatings of a controlled thickness by judicious use of composition of the liquid precursors, facilitating the scale-up to industrially relevant applications. Sol-gel methods however are known for developing cracks inside the thick coating, particularly in complex geometries of the substrate [13].

The sol-gel procedure for alumina coating is typically carried out by acid hydrolysis and polycondensation of diluted aluminium alkoxide (i.e. isopropoxide, butoxide) [3]. The resulting colloidal particles reach specific surface energy of adsorption tendency that could alleviate metal complex geometries. The hydrolysis of alkoxides $\left(M(O R)_{x}\right)$ produces metal hydroxyl bonds $(M-O H)$, as part of hydroxyl lingand compounds $\left((R O)_{x-1} M-O H\right)$, by a 
nucleophilic substitution mechanism, as described by equation (1). This reaction is identical to Lewis base attacking a Lewis acid and proton transfers from the $\mathrm{H}_{2} \mathrm{O}$ molecules to $\left(M(O R)_{x}\right)$, leaving the molecule in a transition state until the alcohol is released [14].

$$
-M-\left(O R_{x}\right)+H_{2} O \leftrightarrow\left(O R_{x}\right)-M-O H+R O H
$$

The condensation is also a nucleophilic attack that follows the hydrolysis and is described by equation (2)). A lone pair of oxygen molecules of the metal hydroxide $(R O)_{x-1} M-O H$ attacks the partially positive metal (M), leaving the hydroxide of the metal in a transition state, $(R O)_{x-1} M-O H$ molecules linked together or with $M(O R)_{x}$, and producing $(R O)_{x-1} M-O-M(R O)_{x-1}$. These are the metal and oxygen bridges which are responsible for forming 3D networks [15].

$$
\begin{aligned}
\left(O R_{x-1}\right)-M & -O H+\left(O R_{x-1}\right)-M-O H \\
\leftrightarrow & \left(O R_{x-1}\right)-M-O-M-\left(O R_{x-1}\right)+H_{2} O
\end{aligned}
$$

Truyen et al. [16], Masalski et al. [17], Sanz et al. [8] and Valentini et al. [18] investigated the deposition of $\gamma-\mathrm{Al}_{2} \mathrm{O}_{3}$ by sol-gel on flat metallic substrates. They prepared the sol-gel by following Yoldas' method [18] with various adjustments (i.e. starting composition and operating conditions of temperature and pressure). The method consisted of mixing aluminium alkoxide (isopropoxide or tri-sec-butoxide) with an excess of water at approximately $80-85^{\circ} \mathrm{C}$ under vigorous stirring. The sol was clarified using a peptization process by adding an acid, which reduced the level of heterogeneity by breaking the large particles for better control of the kinetics of the hydrolysis. The coating was characterised by thickness gauge, surface morphology analysis, ultrasonic adherence, thermal resistance, rheological and porosity distribution tests. Truyen et al. [16] allowed the sol to age until thixotropic properties began to emerge, which was the key step to develop a thin and uniformly spread coating of 0.1-10 $\mu \mathrm{m}$ thickness. Valentini et al. [18] investigated the effect 
of the acid and water content on viscosity of the sol and reported a range of optimal compositions for a uniformly spread coating of an approximate thickness of $30 \mu \mathrm{m}$. Alumina powder was recommended to be added to the sol using multiple depositions of diluted solutions to achieve a controlled adhesiveness. Unlike the samples with low loads (i.e. 1 or 2 deposition cycles) which demonstrated almost no mass loss under ultrasound tests, those of large loads (i.e. 3 or 4 deposition cycles) demonstrated mass losses of over 70\%. Similar results were reported by Guglielmi [12] who emphasised that the coating above a certain thickness would exhibit poor protective capabilities owing to development of cracks and malformations in the coating structure. Sanz et al. [8] investigated a method of coating metallic wire-mesh for the catalytic combustion of soot by varying acid concentration, water content, solid content and polyvinyl alcohol (PVA) as a polymeric binder. The role of the PVA was pertinent to reduce the cracks and improve the adhesiveness of the metallic substrates. Giani et al. [4] achieved a $20 \mu \mathrm{m}$ layer of $\mathrm{Al}_{2} \mathrm{O}_{3}$ coating on metallic foams. The role of viscosity of the gel was investigated through rheological tests by varying the sol-gel parameters such as water content, $\mathrm{pH}$ and ageing. By increasing the solid content and the acid content, the viscosity of the sol-gel was almost constant, until it increased after $48 \mathrm{~h}$. In addition, the formation of intertwined networks of polymers, as a result of ageing for $72 \mathrm{~h}$, increased the viscosity of the sol-gel, resulting in good reproducibility. The coating showed good adhesiveness when tested in an ultrasonic bath and only 4 mass $\%$ of the original loading was lost.

With the emphasis on smaller, cleaner and more energy-efficient process units, the implementation of a packing that promotes phenomena of transfer of mass and heat while keeping a low-pressure drop is necessary [20]. Metallic packing with a three-dimensional structure such as a mesh-based structure would deliver promising phase contacts in multiphase process applications (i.e. distillation, absorption, adsorption, catalytic systems, 
etc.), reducing both capital and operating costs. Dixon rings of the size $1 / 4$ in are stainless steel mesh types of packing which are wrapped in a cylindrical shape as shown in Figure 1. They are produced by Croft Filters Ltd using an imperial measurement system. Packing with such physical properties and geometrical orientation is necessary, especially in applications that include gas and liquid flow [21], such as the trickle bed reactor [22]. As demonstrated in Table 1, when compared with similar packings, Dixon rings offer a larger surface area. The hydrodynamics of Dixon rings were studied by our team and were demonstrated to offer promising mixing capabilities and low pressure drops through the mesh openings [23].

In this work, $\alpha-\mathrm{Al}_{2} \mathrm{O}_{3}$ deposition on stainless steel mesh Dixon rings is investigated under controlled coatings. The resulting surface properties (thickness, morphology and elemental composition) and mechanical properties (i.e. viscosity and adhesiveness) are discussed when the sol-gel coating parameters (i.e. the metal amount, the acid concentration, the mixing time and the ageing time) were varied.

\section{Experimental}

\subsection{Materials}

Dixon rings 1/4 in (stainless steel 316) were supplied by Croft Filters Ltd and were used as a substrate for the coating. The data on the structural size were provided by the supplier and are illustrated in Table 2. Aluminium isopropoxide (AIP, Aldrich) was used as the metal alkoxide precursor. Hydrochloric acid (ACS reagent, Aldrich) was used as a catalyst for the peptization of the sol, while Polyethylenimine (PEI, Aldrich) was used as a binder. Deionized and distilled water was obtained by Milli-Q water filtration system (Merck). Names, molecular formulas, stated purity and source of all chemicals used in this work are presented in Table 3. 


\subsection{Coating method}

AIP powder was hydrolysed into isopropanol and aluminium hydroxide by using an excess of $\mathrm{H}_{2} \mathrm{O}$ at $353 \mathrm{~K}$ for at least 15 minutes under vigorous stirring (750 rpm) to reduce mass transfer limitation. Hydrochloric acid $(\mathrm{HCl})$ was then added dropwise to catalyse the peptization of aluminium hydroxide. The mixture was agitated while heating at $353 \mathrm{~K}$ until it became a transparent solution and then aged to establish an intertwined network of alumina. Dixon rings were degreased in an alkaline cleaner by using an ultrasonic bath for 30 mins at $348 \mathrm{~K}$, dip-coated in the prepared mixture using an in-house dip-coater at a constant speed of $2.64 \mathrm{~cm} / \mathrm{min}$ and calcined at $773 \mathrm{~K}$ for $1 \mathrm{~h}$ to eliminate the PEI and reach a continuous film of $\alpha-\mathrm{Al}_{2} \mathrm{O}_{3}$. The range of different parameters that have been tested are presented in Table 4.

\subsection{Samples characterisation}

The thickness and morphology of the coating were characterised by optical microscopy (Zeiss, magnification: 10X, 0.20 HD) and scanning electron microscopy (SEM JEOL JSM$7800 \mathrm{~F}$ ) operated at $20 \mathrm{kV}$. The viscosity of the coating solution was assessed by a capillary glass viscometer (Viscometer U Tube, BS/U BS188, Type C, VT/92056) with the nominal constants of 0.03 calibrated using distilled water, and met the ISO 17025 requirements. The chemical composition of the surface of the coating was analysed by Electron-dispersive spectroscopy (EDS Shimadzu EDX 8000). The alumina powder (weighing $0.28 \mathrm{~g}$ ) was pretreated at $473 \mathrm{~K}$ in a vacuum oven for $4 \mathrm{~h}$. The powders were then calcined at temperatures ranging from 773-1073 $\mathrm{K}$ and milled. The surface area and porosity were characterised by nitrogen adsorption using Micromeritics 3Flex Surface Characterisation Analyser which was operated with a relative pressure between $1.3 \times 10^{-9}$ to 1 . The surface area was determined using the Brunauer-Emmett-Teller (BET) method operated with no degassing and a bath temperature of $77 \mathrm{~K}$. The pore-volume and the pore-distribution were obtained by using the Harkins and Jura adsorption isotherm method. 
The coating load was evaluated by weighing the samples before and after coating using an analytical balance (Sartorius $2001 \mathrm{MP}$, resolution: $0.1 \mathrm{mg}$ ). The coating adhesiveness was investigated by subjecting the coating to thermal oxidation at temperatures up to $1273 \mathrm{~K}$ for 3 $\mathrm{h}$ and ultrasound tests at $100 \mathrm{~W}$ for 10 mins. The validity of the coating method was confirmed by carrying out replicas of the assays. All results are presented as the average of at least two replicates along with the standard deviation shown on the error bars in the figures.

\section{Results and discussions}

It was essential to allow the hydrolysis and the condensation to work in tandem during the mixing, affecting the production of hydroxides, molecular mass and thus the sol-gel solution viscosity. Aged solutions are anticipated to encounter an increase in viscosity owing to a change in the morphology of the cross-linking polymers, leading the boundary conditions that reduce the gelation to be investigated [15]. Herein, the kinetics of the peptization and ageing were first investigated, and the results helped characterisation of the coating properties when the starting solution contents (i.e. acid, water, alumina and the binder) were varied.

\subsection{Sol-gel kinetics}

The peptization and ageing process are competitive processes since the kinetics of changes in surface charges are strongly affected by the initial coating parameters. Herein, effects of coating parameters (i.e. $\mathrm{HCl}$ content, water content and ageing time) on the kinetics of peptization were investigated for an extended mixing time of one week.

\subsubsection{HCl content}

Figure 2 shows that the coating load per surface area increased initially for both $\mathrm{Al} / \mathrm{HCl}$ ratios $(0.17$ and $0.25(\mathrm{~mol} / \mathrm{mol}))$, reaching the maximum value of approximately 1.301 $\mathrm{mg} / \mathrm{cm}^{2}$ after $96 \mathrm{~h}$ while the further increase of mixing produces the similar coating load. The 
increase in the load is explained by the deflocculation of alumina particles, as a result of an increase in the surface charge, moving away from the isoelectric point of the hydrolysed alumina colloid and reducing the agglomeration kinetic rate of particles [24]. The load stabilised due to the pacification of changes of the particle charges under the effect of the shear forces. Therefore, when the mixing took place for $24 \mathrm{~h}$, a fine coating was produced, as shown in Figure 3. After 96 h, the mixtures were transparent, and no particulates were visually observed. The image by optical microscope (Figure 3) depicted uniformly spread films over Dixon rings with a thickness of around $20 \mu \mathrm{m}$.

\subsubsection{Water content}

A similar trend was observed when the effect of the mixing time was investigated for $\mathrm{Al} / \mathrm{H}_{2} \mathrm{O}$ $=0.01$ and $0.013(\mathrm{~mol} / \mathrm{mol})$, as shown in Figure 4. The load kept increasing with the mixing time, until it became constant after $96 \mathrm{~h}$. The ratio of $\mathrm{Al} / \mathrm{H}_{2} \mathrm{O}$ of $0.01(\mathrm{~mol} / \mathrm{mol})$ demonstrated a steady increase in the load after $48 \mathrm{~h}$ and stabilization after $96 \mathrm{~h}$. The ratio of $\mathrm{Al} / \mathrm{H}_{2} \mathrm{O}$ of 0.013 however demonstrated a significant increase in the load after $48 \mathrm{~h}$ (load of $1.41 \mathrm{mg} / \mathrm{cm}^{2}$ ) and stabilisation after $96 \mathrm{~h}$. These results reflect the level of dispersion of hydroxyl bonds, the randomness in the surface charges and thus mobility of the particles in the solution [14].

\subsubsection{Ageing time}

The previous investigations showed that $96 \mathrm{~h}$ of mixing was enough to stabilise the coating load (section 3.1), and therefore this time was used to understand the effect of time on ageing. As expected, the general trends in Figure 5 and Figure 6 show that the coating load increased with the ageing time, confirming the development of an intertwined polymeric network. The measurements were extended to the course of $96 \mathrm{~h}$, where no difference in load change was found. A uniformly spread and adhesive coating was achieved at $\mathrm{HCl} / \mathrm{Al}=0.25$ $(\mathrm{mol} / \mathrm{mol})$ and $\mathrm{Al} / \mathrm{H}_{2} \mathrm{O}=0.01(\mathrm{~mol} / \mathrm{mol})$ after $48 \mathrm{~h}$ of ageing. 


\subsection{Effect of the starting composition on coating properties}

The steady properties of the coating after $96 \mathrm{~h}$ of perpetization time and $48 \mathrm{~h}$ of ageing were investigated by varying the starting composition of the coating. Finding the adequate starting composition is pertinent to the morphology of the coating because the rate and extent of the hydrolysis and condensation reactions are essentially driven by these ratios [15]. The stability of the prepared sol-gel solutions was determined based on its opacity to transparency range and the formation of agglomerates after drying the coated Dixon rings.

\subsubsection{Effect of $\mathrm{HCl}$ content in the starting mixture}

Strong acid $(\mathrm{HCl})$ was added in order to reduce the heterogeneity level in the mixtures and give better control of the sol formation. The acid itself did not take part in the reaction but modified the properties of the mixture, by promoting changes in particles charges and thus the relevant particle sizes. Figure 7 shows the coating load and viscosity of the sol mixture as a function of the acid concentration in the starting mixture. The coating load was constant until it mounted at $\mathrm{HCl} / \mathrm{Al}=0.33(\mathrm{~mol} / \mathrm{mol})$ in a similar way to the trends described in Yoldas [19]. At the $\mathrm{HCl} / \mathrm{Al}$ range from 0.13 to 0.25 ( $\mathrm{mol} / \mathrm{mol})$, transparent mixtures were produced, indicating a good dispersion. The viscosity was almost constant at $0.0035 \mathrm{~Pa}$.s until it increased to a significant value of $0.025 \mathrm{~Pa} . \mathrm{s}$ for $\mathrm{HCl} / \mathrm{Al}=0.33(\mathrm{~mol} / \mathrm{mol})$, confirming the development of the gelation process, led by the formation of hydrogen bonding between the surface hydroxyl groups as well as the building of the loose polymeric 3D networks between the particles [18].

The correlation between the viscosity of the solution and the coating load pointed out the key role of the flow behaviour of the solution in development of the coating on Dixon substrate. The results of the rheologic measurements are useful to explain the profiles of coating adhesiveness when the coated Dixon rings were assessed by the ultrasonic adhesion test for a period of $10 \mathrm{~min}$, as shown in Figure 8. A HCl/Al ratio of $0.25(\mathrm{~mol} / \mathrm{mol})$ provided a load 
drop that was ranging from $19-30 \%$. A HCl/Al ratio of $0.33(\mathrm{~mol} / \mathrm{mol})$ however demonstrated a major drop (ca. 90\%) of the original load. The ratio of $\mathrm{HCl} / \mathrm{Al}$ was then considered for the rest of the work as it demonstrated a good adhesiveness of the coating.

\subsubsection{Effect of $\mathrm{Al}$ content in the starting mixture}

As shown in Figure 9, the coating load and the sol-gel viscosity increased monotonically by increasing the alkoxide concentration, stabilized at $\mathrm{Al} / \mathrm{H}_{2} \mathrm{O}=0.017(\mathrm{~mol} / \mathrm{mol})$, and then increased at $\mathrm{Al} / \mathrm{H}_{2} \mathrm{O}=0.02(\mathrm{~mol} / \mathrm{mol})$. A similar trend was observed by Valentini et al. [18] and was discussed by the wetting potential of the substrate. This is confirmed by the viscosity profiles, which followed similar trend to those of the coating load (i.e. an increase from 0.0035 to $0.018 \mathrm{~Pa} . \mathrm{s}$ when $\mathrm{Al} / \mathrm{H}_{2} \mathrm{O}$ ratio was increased from 0.014 to $0.02(\mathrm{~mol} / \mathrm{mol})$, demonstrating role of water in the hydrolysis and polycondensation process. Figure $\mathbf{1 0}$ shows the profiles of the coating load under ultrasound tests for 0.02 and $0.01 \mathrm{~mol} / \mathrm{mol}$ water content, respectively. The former water content provided poor adhesiveness since about $80 \%$ of the coating load was lost after $10 \mathrm{~min}$. The lack of dispersion in water limited the formation of $\mathrm{OH}$ groups. The formation of soluble oxo-ligands in water was then inhibited by the development of repulsive forces, reducing of the electric double layer and leading to the agglomeration of the particles, and thus a poor adhesion to the substrate. When the $\mathrm{Al} / \mathrm{H}_{2} \mathrm{O}$ ratio was reduced to $0.01(\mathrm{~mol} / \mathrm{mol})$, only $18-23 \%$ of the load was lost under the ultrasonic test, showing a relatively good dispersion of alumina particles, which was an indication of arranged particles in the $3 \mathrm{D}$ polymeric network. The ratio of $\mathrm{Al} / \mathrm{H}_{2} \mathrm{O}=0.01(\mathrm{~mol} / \mathrm{mol})$ was then chosen for the following study.

\subsection{Effect of the PEI as binder}

Polymeric binders are known for improving adhesion and reducing the cracks during the deposition process [25]. Figure 11 shows the effect of PEI as binder on the coating load. The addition of binder did not have any effect on the coating load for concentrations below 1.05 
$\mathrm{g} / \mathrm{L}$. Conversely, the deposition was enhanced steadily from $1.05 \mathrm{~g} / \mathrm{L}$ to $2.1 \mathrm{~g} / \mathrm{L}$, whilst the further increase of the binder concentration (more than $2.1 \mathrm{~g} / \mathrm{L}$ ) resulted in a sharp increase of the coating load. Optical micrographs presented in Figure 12 revealed cracks in the coating and filled openings of the Dixon rings for concentration of the PEI higher than $2.6 \mathrm{~g} / \mathrm{L}$. This could be explained by the high surface positive charge that would have promoted the flocculation of alumina particles and reduced its stability [26]. Conversely, the binder concentration of $2.1 \mathrm{~g} / \mathrm{L}$ resulted in the highest load whilst it kept a good surface uniformity as shown in the micrographs of Figure 12. The binder was then effective in reducing the surface charges (i.e. particularly relevant to hydroxyl functional groups that are responsible for the attachment of the film to the substrate) and thus absorbing the effect of capillary forces onto the surfaces of the alumina particles. The adhesion was improved compared to Dixon rings coated with no binder (i.e. the $12-15 \%$ of the initial mass was lost when subjected for 10 mins in the ultrasound adhesive test, as shown in Figure 13, whilst the samples prepared without PEI lost 19-30\%).

\subsection{Effect of the coating cycles}

A multiple cycle deposition procedure for Dixon rings was probed in order to prepare a coating of controlled thickness and loading properties. When the same procedure was followed for each deposition, a positive correlation between the alumina coating properties and the number of depositions was obtained as demonstrated in Figure 14 and depicted in

Figure 15. The coating load increased from $1.13 \mathrm{mg} / \mathrm{cm}^{2}$ to $1.84 \mathrm{mg} / \mathrm{cm}^{2}$ after four depositions. Ultrasonic adhesive tests, as shown in Figure 16, demonstrated that the multiple depositions reduced the adhesion of the coating to the substrate. For the first, second and third deposition cycles, the coating mass decreased by $19.8 \%, 31.7 \%$ and $61.4 \%$, respectively. After the fourth deposition cycle, the coating lost its homogeneity and multiple cracks were formed (Figure 15), whilst the first three cycles had similar morphology and a 
slight increase in the load (Figure 14). The drastic increase in the coating load reflects a change in the surface roughness. Such behaviour could be explained by the effects of thermomechanical stresses that could be developed during the thermal treatment of the coating, whilst a potential chemical effect of hydroxyl groups should not be ignored.

\subsection{The morphology of the coating}

\subsubsection{Coating distribution over Dixon rings}

The images from the SEM for Dixon rings (Figure 17) showed that the coating was more effective around the interstitial area in the vicinity of the pore openings and intersections of the wires but was less effective on the convex area of the wires. This can be explained by the wetting behaviour of the Dixon rings by the liquid precursor, which favoured the opening pore area by capillary wetting.

EDS tests were conducted on the same sample by selecting two arbitrary points, one near the opening vicinity, where the coating is concentrated, and the other on the wire, where the coating is sparse, as shown in Figure 18 and Figure 19- spectra 8 and 9 show $42.1 \% \mathrm{Al}$ and $51 \%$ for $\mathrm{O}$ in the vicinity of the pores and $11.4 \% \mathrm{Al}$ and $20.2 \% \mathrm{O}$ on the wire, respectively. In order to check if any interfacial layers between the coating and substrate was formed by the chemical bonds, a cross-section cut of a coated Dixon ring was carried out to assess potential diffusion of alumina into the wires. Figure 19 (b) shows some traces of alumina within the wires but distribution at the boundary substrate-coating was not uniform (i.e. unlike $\mathrm{Cr}$ and $\mathrm{Fe}$ in Figures 19 (c) and (d), respectively). This shows that the diffusion or migration of $\mathrm{Al}$ to the substrate was a function of the coating distribution of the mesh-wire (i.e. it was concentrated particularly in locations in the vicinity of the wire's cross-section. The adhesion of the coating was therefore mainly driven by the chemical bonding at negligible mass transfer diffusion into the substrate. 


\subsubsection{Effect of calcination temperature}

The effect of calcination temperature on the surface area and porosity of alumina was investigated. The results are illustrated in Table 5. Alumina has a mesoporous structure with strong contribution of micropores to the overall surface structure. The surface area of the sample calcined at $773 \mathrm{~K}\left(300.7 \mathrm{~m}^{2} / \mathrm{g}\right)$ was higher than the one calcined at $1073 \mathrm{~K}(245.6$ $\mathrm{m}^{2} / \mathrm{g}$ ). The decrease of the surface area correlates well with the increase of the pores sizes, particularly at temperatures higher than $773 \mathrm{~K}$ [25].

The SEM image (Figure 20) shows the effect of the calcination temperature at $773 \mathrm{~K}, 1073$ $\mathrm{K}$ and $1273 \mathrm{~K}$ on the morphology of the coating. Similar structure, glass-like, is observed at $773 \mathrm{~K}$ and $1073 \mathrm{~K}$ calcination temperature, which confirm the surface properties in Table 5, whilst at $1273 \mathrm{~K}$, some particles agglomerated into aggregates are observed. The alumina particles grew due to the increasing nucleation rate and their migration promoted the surface thickness [15]. In addition, few cracks were observed at this temperature which might be attributed to the residual stress, as a result of the difference between the thermal expansion coefficient of the metal and the coating, and to the reduction of density of hydroxyl groups [27]. The coating load was measured for all temperatures and was the same, demonstrating a good thermal resistance up to $1273 \mathrm{~K}$.

\section{Conclusions}

Well-adhered alumina with a thickness up to $20 \mu \mathrm{m}$ was deposited on Dixon rings using a simple sol-gel technique. In order to overcome the difficulties associated with coating the stainless steel of complex geometry and achieve excellent adhesion, the effects of the initial composition on the coating properties were investigated. The ratios of $0.25(\mathrm{~mol} / \mathrm{mol})$ for $\mathrm{HCl} / \mathrm{Al}, 0.01(\mathrm{~mol} / \mathrm{mol})$ for $\mathrm{Al} / \mathrm{H}_{2} \mathrm{O}, 48 \mathrm{~h}$ for the aging time, $96 \mathrm{~h}$ for the mixing time and 2.1 $\mathrm{g} / \mathrm{L}$ of PEI binder formed a controlled and suitable coating of alumina on the Dixon ring. The coating was found free of microscopic cracks. Increasing the thickness was successfully 
achieved through multiple cycles but two cycles were found suitable, meeting the viscosity boundary of 0.0035 (Pa.s).

\section{Acknowledgments}

The authors acknowledge the financial support from the Centre for Global Eco-Innovation at Lancaster University, the European Regional Development Fund (Grant Reference:

03R17P01835 - Eco-Innovation Cheshire and Warrington) and Croft Filters Ltd, Warrington, UK.

\section{References}

[1] Shen $\mathrm{YZ}$, Guo XZ, Lin $\mathrm{YB}$, Tao $\mathrm{J} . \mathrm{Al}_{2} \mathrm{O}_{3}$ coatings fabricated on stainless steel/aluminium composites by microarc oxidation. Surf. Eng. 2014;30:735-740.

[2] Pinzon,AV, Urrego KJ, Gonzalez-Hernandez A, Ortiz MR, Galvis, FV. Corrosion protection of carbon steel by alumina-titania ceramic coatings used for industrial applications. Ceramics International. 2018;44:21765-21773.

[3] Figueira R, Fontinha I, Silva C, Pereira E. Hybrid Sol-Gel Coatings, Smart and Green Materials for Corrosion Mitigation. Coatings.2016;6 (12):2-19.

[4] Gancarczyk A, Sindera K, Iwaniszyn M, Piatek M, Macek, W, Jodlowski PJ, Wronski S, Sitarz M, Lojewska J, Kolodziej A. Metal Foams as Novel Catalyst Support in Environmental Processes. Catalysts. 2019; 9:587.

[5] Vander Wal RL, Hall LJ. Carbon nanotube synthesis upon stainless steel meshes. Carbon. 2003;41:659-672.

[6] Cernuschi F, Lorenzoni L, Capelli S, Guardamagna C, Karger M, Vaßen R., Von Niessen K, Markocsan N, Menuey J, Giolli C. Solid particle erosion of thermal spray and physical vapour deposition thermal barrier coatings. Wear. 2011;271:2909-2918.

[7] Takeda S, Suzuki S, Odaka H, Hosono H. Photocatalytic $\mathrm{TiO}_{2}$ thin film deposited onto glass by DC magnetron sputtering. Thin Solid Films. 2001;392:338-344.

[8] Sanz O, Banús ED, Goya A, Larumbe H, Delgado JJ, Monzón A, Montes M. Stacked wire-mesh monoliths for VOCs combustion, Effect of the mesh-opening in the catalytic performance. Catal. Today. 2017;296:76-83.

[9] Sun H, Shu Y, Quan X, Chen S, Pang B, Liu ZY. Experimental and modeling study of selective catalytic reduction of $\mathrm{NO}_{x}$ with $\mathrm{NH}_{3}$ over wire mesh honeycomb catalysts. Chem. Eng. J. 2010;165:769-775

[10] Mamaliga I, Sidor D, Condurat C, Iacob Tudose ET. Hydrodynamics and mass transfer coefficients for a modified Raschig ring packed column. Heat Mass Transf. 2014;50:1385-1392

[11] Meille V, Pallier S, Rodriguez P. Reproducibility in the preparation of alumina slurries for washcoat application-Role of temperature and particle size distribution. Colloids Surfaces A Physicochem. Eng. Asp. 2009;336:104-109. 
[12] Guglielmi M. Sol-Gel Coatings on Metals, J. Sol-Gel Sci. Technol. 1997;8:443-449.

[13] Sharma GS, Sugavaneswaran, M, Vijayalakshmi U,,Prakash R. Influence of gammaalumina coating on surface properties of direct metal laser sintered $316 \mathrm{~L}$ stainless steel. Ceramics International. 2016;45:13456-13463

[14] Zhu QL, Li H, Wang Y, Zhou Y, Zhu AM, Chen X, Li XN, Chen YF, Lu HF. Novel metallic electrically heated monolithic catalysts towards VOC combustion. Catal. Sci. Technol. 2019; 9:6638-6646.

[15] Fabes BD, Zelinski BJJ, Uhlmann DR. Sol-Gel Ceramic Coatings, Ceramic Film and Coatings. J. B. Watchtman and R. A. Haber, ed. Noyes Publications;1993.224-283.

[16] Truyen D, Courty M, Alphonse P, Ansart F. Catalytic coatings on stainless steel prepared by sol-gel route. Thin Solid Films. 2006;495:257-261.

[17] do Nascimento S, Dias AJD, da Silva GM, Caldeira HD, Louro LHL, Gonzalez WD. Characterization of Niobia-alumina Deposited by the Sol-gel Process on Carbon Steel. Mater Res-Ibero-Am J. 2018; 21:e20170525 to change.

[18] Valentini M, Groppi G, Cristiani C, Levi M, Tronconi E, Forzatti P. The deposition of $\gamma-\mathrm{Al}_{2} \mathrm{O}_{3}$ layers on ceramic and metallic supports for the preparation of structured catalysts. Catal. Today. 2001;69:307-314.

[19] Yoldas BE., Transparent activated nonparticulate alumina and method of preparing same.U.S. Patent 3,941,719, Mar. 2, 1976.

[20] Pavlenko AN, Zeng J, Pecherkin NI, Zhukov VE, Volodin OA. Separation efficiency and pressure drop of SiC ceramic and Mellapak structured packings. J. Eng. Thermophys. 2016;25:1-14.

[21] Llano JJ, Rosal R, Sastre H, Díez FV. Determination of Wetting Efficiency in TrickleBed Reactors by a Reaction Method. Ind. Eng. Chem. Res. 1997;36:2616-2625.

[22] Schwidder S, Schnitzlein K. A new model for the design and analysis of trickle bed reactors. Chem. Eng. J. 2012;207-208:758-765.

[23] Aldehani M, Alzahrani F, tSaoir MNA, Fernandes DLA, Assabumrungrat S, Aiouache F. Kinetics and reactive stripping modelling of hydrogen isotopic exchange of deuterated waters. Chem. Eng. Process. Process Intensif. 2016;108:58-73.

[24] Shalygin AS, Kozhevnikov IV, Gerasirnov EY, Andreev AS, Lapina OB, Martyanov $\mathrm{ON}$. The impact of $\mathrm{Si} / \mathrm{Al}$ ratio on properties of aluminosilicate aerogels. Micropor. Mesopor. Mat.2017; 251:105-113.

[25] Pandey M, Tyagi K, Mishra P, Saha D, Sengupta K, Islam SS. Nanoporous morphology of alumina films prepared by sol-gel dip coating method on alumina substrate. J. Sol-Gel Sci. Technol. 2012;64:282-288.

[26] Hubert T, Schwarz J, Oertel B. Sol-gel alumina coatings on stainless steel for wear protection. J. Sol-Gel Sci. Technol. 2006;38:179-184.

[27] Nguefack M, Popa AF, Rossignol S, Kappenstein C. Preparation of alumina through a sol-gel process. Synthesis, characterization, thermal evolution and model of intermediate boehmite. Phys. Chem. Chem. Phys. 2003;5:4279-4289. 


\section{Legends of the tables and the figures}

Table 1. Physical properties for random packings

Table 2. Dixon rings $1 / 4$ in structural data.

Table 3. Chemicals used in this work

Table 4. Sol-gel parameters.

Table 5. The properties of alumina calcined at $773 \mathrm{~K}$ and $1073 \mathrm{~K}$.

Figure 1. Stainless steel packing Dixon ring $1 / 4$ in, (a) randomly packed (b) single element, produced by Croft Filters Ltd.

Figure 2. Effect of mixing time on the coating load for (Black circles) $\mathrm{Al} / \mathrm{HCl}=0.17$ $(\mathrm{mol} / \mathrm{mol})$ and $(\mathrm{Red}$ triangles$) \mathrm{Al} / \mathrm{HCl}=0.25(\mathrm{~mol} / \mathrm{mol})$. Coating parameters: $\mathrm{Al} / \mathrm{H}_{2} \mathrm{O}=0.01$ $(\mathrm{mol} / \mathrm{mol})$, aging time $=168 \mathrm{~h}$, calcination temperature $=773 \mathrm{~K}$.

Figure 3. Optical micrograph (10X) of coated Dixon ring with: (a) mixing time $=24 \mathrm{~h}$ and (b) mixing time $=96 \mathrm{~h}$. Coating parameters: $\mathrm{HCl} / \mathrm{Al}=0.25(\mathrm{~mol} / \mathrm{mol}), \mathrm{Al} / \mathrm{H}_{2} \mathrm{O}=0.01(\mathrm{~mol} / \mathrm{mol})$, aging time $=168 \mathrm{~h}$ and calcination temperature $=773 \mathrm{~K}$.

Figure 4. Effect of mixing time on the coating load for: (Black circles) $\mathrm{Al} / \mathrm{H}_{2} \mathrm{O}=0.01$ $(\mathrm{mol} / \mathrm{mol})$ and $\left(\right.$ Red triangles) $\mathrm{Al} / \mathrm{H}_{2} \mathrm{O}=0.013(\mathrm{~mol} / \mathrm{mol})$. Coating parameters: $\mathrm{HCl} / \mathrm{Al}=0.25$ $(\mathrm{mol} / \mathrm{mol})$ aging time $=168 \mathrm{~h}$ and calcination temperature $=773 \mathrm{~K}$.

Figure 5. Effect of ageing time on the coating load for: (Black circles) $\mathrm{HCl} / \mathrm{Al}=0.17$ (mol/ $\mathrm{mol}$ ) and (Red triangles) $\mathrm{HCl} / \mathrm{Al}=0.25(\mathrm{~mol} / \mathrm{mol})$. Coating parameters: $\mathrm{Al} / \mathrm{H}_{2} \mathrm{O}=0.01$ $(\mathrm{mol} / \mathrm{mol})$, mixing time $=93 \mathrm{~h}$ and calcination temperature $=773 \mathrm{~K}$

Figure 6. Effect of ageing time on the coating load for: (Black circles) $\mathrm{Al} / \mathrm{H}_{2} \mathrm{O}=0.01$ $(\mathrm{mol} / \mathrm{mol})$ and $\left(\right.$ Red triangles) $\mathrm{Al} / \mathrm{H}_{2} \mathrm{O}=0.013(\mathrm{~mol} / \mathrm{mol})$. Coating parameters: $\mathrm{HCl} / \mathrm{Al}=0.25$ $(\mathrm{mol} / \mathrm{mol})$ and mixing time $=96 \mathrm{~h}$ and calcination temperature $=773 \mathrm{~K}$.

Figure 7. The influence of $\mathrm{HCl} / \mathrm{Al}$ ratio in the starting mixture on: (Black circles) Coating load and (Red Triangles) viscosity. Coating parameters: $\mathrm{Al} / \mathrm{H}_{2} \mathrm{O}=0.01(\mathrm{~mol} / \mathrm{mol})$, mixing time $=96 \mathrm{~h}$, aging time $=48 \mathrm{~h}$ and calcination temperature $=773 \mathrm{~K}$.

Figure 8. Ultrasonic adhesiveness test - influence of ultrasound bath time on the coating load for: $($ Black circles) $\mathrm{HCl} / \mathrm{Al}=0.25(\mathrm{~mol} / \mathrm{mol})$ and $($ Red triangles $) \mathrm{HCl} / \mathrm{Al}=0.33(\mathrm{~mol} / \mathrm{mol})$. Coating parameters: $\mathrm{Al} / \mathrm{H}_{2} \mathrm{O}=0.01(\mathrm{~mol} / \mathrm{mol})$, mixing time $=96 \mathrm{~h}$, aging time $=48 \mathrm{~h}$ and calcination temperature $=773 \mathrm{~K}$.

Figure 9. Influence of $\mathrm{Al} / \mathrm{H}_{2} \mathrm{O}$ ratio in the starting mixture on: (Black circles) coating load and (Red Triangles) viscosity. Coating parameters: $\mathrm{HCl} / \mathrm{Al}=0.021(\mathrm{~mol} / \mathrm{mol})$, mixing time $=$ $96 \mathrm{~h}$, aging time $=48 \mathrm{~h}$ and calcination temperature $=773 \mathrm{~K}$.

Figure 10. Ultrasonic adhesiveness test - influence of ultrasound bath time on the coating load for: (Black circles) $\mathrm{Al} / \mathrm{H}_{2} \mathrm{O}=0.02\left(\mathrm{~mol} / \mathrm{mol}\right.$ ) and (Red triangles) $\mathrm{Al} / \mathrm{H}_{2} \mathrm{O}=0.01$ 
$(\mathrm{mol} / \mathrm{mol})$. Coating parameters: $\mathrm{HCl} / \mathrm{Al}=0.25(\mathrm{~mol} / \mathrm{mol})$, mixing time $=96 \mathrm{~h}$, aging time $=$ $48 \mathrm{~h}$ and calcination temperature $=773 \mathrm{~K}$

Figure 11. Effect of binder concentration on the coating load. Coating parameters: $\mathrm{Al} / \mathrm{H}_{2} \mathrm{O}=$ $0.01(\mathrm{~mol} / \mathrm{mol}), \mathrm{HCl} / \mathrm{Al}=0.25(\mathrm{~mol} / \mathrm{mol})$, mixing time $=96 \mathrm{~h}$, ageing time $=48 \mathrm{~h}$ and calcination temperature $=773 \mathrm{~K}$.

Figure 12. Optical micrograph (10X) of coated Dixon ring with using PEI concentration of: (a) $2.6 \mathrm{~g} / \mathrm{L}$ and (b) $2.08 \mathrm{~g} / \mathrm{L}$. Coating parameters: $\mathrm{HCl} / \mathrm{Al}=0.25(\mathrm{~mol} / \mathrm{mol}), \mathrm{Al} / \mathrm{H}_{2} \mathrm{O}=0.01$ $(\mathrm{mol} / \mathrm{mol})$, mixing time $=96 \mathrm{~h}$, aging time $=48 \mathrm{~h}$ and calcination temperature $=773 \mathrm{~K}$

Figure 13. The coating adhesion in ultrasound bath tests with the addition of PEI concentration $=2.1(\mathrm{~g} / \mathrm{L})$. Coating parameters: $\mathrm{Al} / \mathrm{H}_{2} \mathrm{O}=0.01(\mathrm{~mol} / \mathrm{mol}), \mathrm{HCl} / \mathrm{Al}=0.25$ $(\mathrm{mol} / \mathrm{mol})$, mixing time $=96 \mathrm{~h}$, ageing time $=48 \mathrm{~h}$ and calcination temperature $=773 \mathrm{~K}$.

Figure 14. Coating load vs deposition cycles for Dixon rings. Coating parameters: $\mathrm{Al} / \mathrm{H}_{2} \mathrm{O}=$ $0.01(\mathrm{~mol} / \mathrm{mol}), \mathrm{HCl} / \mathrm{Al}=0.25(\mathrm{~mol} / \mathrm{mol})$, mixing time $=96 \mathrm{~h}$, ageing time $=48 \mathrm{~h}$ and calcination temperature $=773 \mathrm{~K}$.

Figure 15. Coupled SEM-EDS results on Dixon ring coated with: (a) one, (b) two, c) three, and d) four deposition cycles. Coating parameters: $\mathrm{Al} / \mathrm{H}_{2} \mathrm{O}=0.01(\mathrm{~mol} / \mathrm{mol}), \mathrm{HCl} / \mathrm{Al}=0.25$ $(\mathrm{mol} / \mathrm{mol})$, mixing time $=96 \mathrm{~h}$, ageing time $=48 \mathrm{~h}$ and calcination temperature $=773 \mathrm{~K}$.

Figure 16. The coating adhesion in ultrasound bath tests for multiple depositions (Black circles) first cycle, (Red triangles) second cycle and (Blue squares) third cycle. Coating parameters: $\mathrm{Al} / \mathrm{H}_{2} \mathrm{O}=0.01(\mathrm{~mol} / \mathrm{mol}), \mathrm{HCl} / \mathrm{Al}=0.25(\mathrm{~mol} / \mathrm{mol})$, mixing time $=96 \mathrm{~h}$, ageing time $=48 \mathrm{~h}$ and calcination temperature $=773 \mathrm{~K}$.

Figure 17. SEM-image of a coated Dixon ring, coating parameters: $\mathrm{Al} / \mathrm{H}_{2} \mathrm{O}=0.01(\mathrm{~mol} / \mathrm{mol})$, $\mathrm{HCl} / \mathrm{Al}=0.25(\mathrm{~mol} / \mathrm{mol})$, mixing time $=96 \mathrm{~h}$, ageing time $=48 \mathrm{~h}$ and calcination temperature $=773 \mathrm{~K}$.

Figure 18. The EDS spectrum for the local points (a) 8 and (b) 9 for the sample in Figure 17.

Figure 19. SEM image of the wire after the cut (a), coupled SEM-EDS mapping (b) Al (c) $\mathrm{Cr}$ (d) Fe results for a cut through a coated Dixon ring. Coating parameters: $\mathrm{HCl} / \mathrm{Al}=0.25(\mathrm{~mol}$ $/ \mathrm{mol}), \mathrm{Al} / \mathrm{H}_{2} \mathrm{O}=0.01(\mathrm{~mol} / \mathrm{mol})$, mixing time $=96 \mathrm{~h}$, ageing time $=48 \mathrm{~h}$ and calcination temperature $=773 \mathrm{~K}$.

Figure 20. SEM images (a, $c$ and e) and EDS images of Al distribution (b, d and $f$ ) of calcined coating. Calcination temperature: $(\mathrm{a}, \mathrm{b})$ at $773 \mathrm{~K},(\mathrm{c}, \mathrm{d})$ at $1073 \mathrm{~K}$ and (e, f) at 1273 $\mathrm{K}$. Coating parameters: $\mathrm{Al} / \mathrm{H}_{2} \mathrm{O}=0.01(\mathrm{~mol} / \mathrm{mol}), \mathrm{HCl} / \mathrm{Al}=0.25(\mathrm{~mol} / \mathrm{mol})$, mixing time $=$ $96 \mathrm{~h}$ and ageing time $=48 \mathrm{~h}$. 
Table 1. Physical properties for random packings.

\begin{tabular}{cccc}
\hline \multirow{2}{*}{ Physical structure } & Berl saddles $1 / 4$ in & Ranching ring $1 / 4$ in & Dixon Rings $1 / 4$ in \\
\hline Specific Area $\mathrm{m}^{2} / \mathrm{m}^{3}$ & {$[22]$} & {$[22]$} & {$[23]$} \\
Void $\%$ & 352 & 610 & 900 \\
\hline
\end{tabular}

Table 2. Dixon rings $1 / 4$ in structural data.

\begin{tabular}{cccc}
\hline Wire diameter $(\mu \mathrm{m})$ & Mesh & $\begin{array}{c}\text { Length of mesh per } \\
\text { Dixon ring }(\mathrm{mm})\end{array}$ & Aperture $(\mu \mathrm{m})$ \\
\hline 160 & $60 \times 60$ & 30 & 271 \\
\hline
\end{tabular}

Table 3. Chemicals used in this work.

\begin{tabular}{lcccc}
\hline Compound & Molecular Formula & Purity (mass \%) & CAS no. & Source \\
\hline Aluminum isopropoxide & $\mathrm{Al}\left[\mathrm{OCH}\left(\mathrm{CH}_{3}\right)_{2}\right]_{3}$ & $\geq 98.0$ & $555-31-7$ & Sigma Aldrich \\
Hydrochloric acid & $\mathrm{HCl}$ & 37 & $7647-01-0$ & Sigma Aldrich \\
Polyethylenimine & $\mathrm{H}\left(\mathrm{NHCH}_{2} \mathrm{CH}_{2}\right)_{n} \mathrm{NH}_{2}$ & $\geq 99.0$ & $9002-98-6$ & Sigma Aldrich \\
\hline
\end{tabular}

Table 4. Sol-gel parameters.

\begin{tabular}{lc}
\hline Parameter & Range \\
\hline $\mathrm{Al}: \mathrm{H}_{2} \mathrm{O}(\mathrm{mol} / \mathrm{mol})$ & $0.005-0.02$ \\
$\mathrm{HCl}: \mathrm{Al}(\mathrm{mol} / \mathrm{mol})$ & $0.13-0.33$ \\
Mixing time $(\mathrm{h})$ & $1-168$ \\
Aging time $(\mathrm{h})$ & $1-96$ \\
Binder concentration $(\mathrm{g} / \mathrm{L})$ & $0.52-2.59$ \\
Number of deposition $(\mathrm{cycle})$ & $1-4$ \\
Calcination temperature $(\mathrm{K})$ & $773-1273$ \\
\hline
\end{tabular}

Table 5. The properties of alumina calcined at $773 \mathrm{~K}$ and $1073 \mathrm{~K}$.

\begin{tabular}{cccc}
\hline & $\begin{array}{c}\text { Surface area } \\
\left(\mathrm{m}^{2} / \mathrm{g}\right)\end{array}$ & $\begin{array}{c}\text { Average pore diameter } \\
(\mathrm{nm})\end{array}$ & $\begin{array}{c}\text { Pore volume } \\
\left(\mathrm{cm}^{3} / \mathrm{g}\right)\end{array}$ \\
\hline $773 \mathrm{~K}$ & 300.7 & 12.4 & 0.41 \\
$1073 \mathrm{~K}$ & 245.6 & 12.6 & 0.46 \\
\hline
\end{tabular}



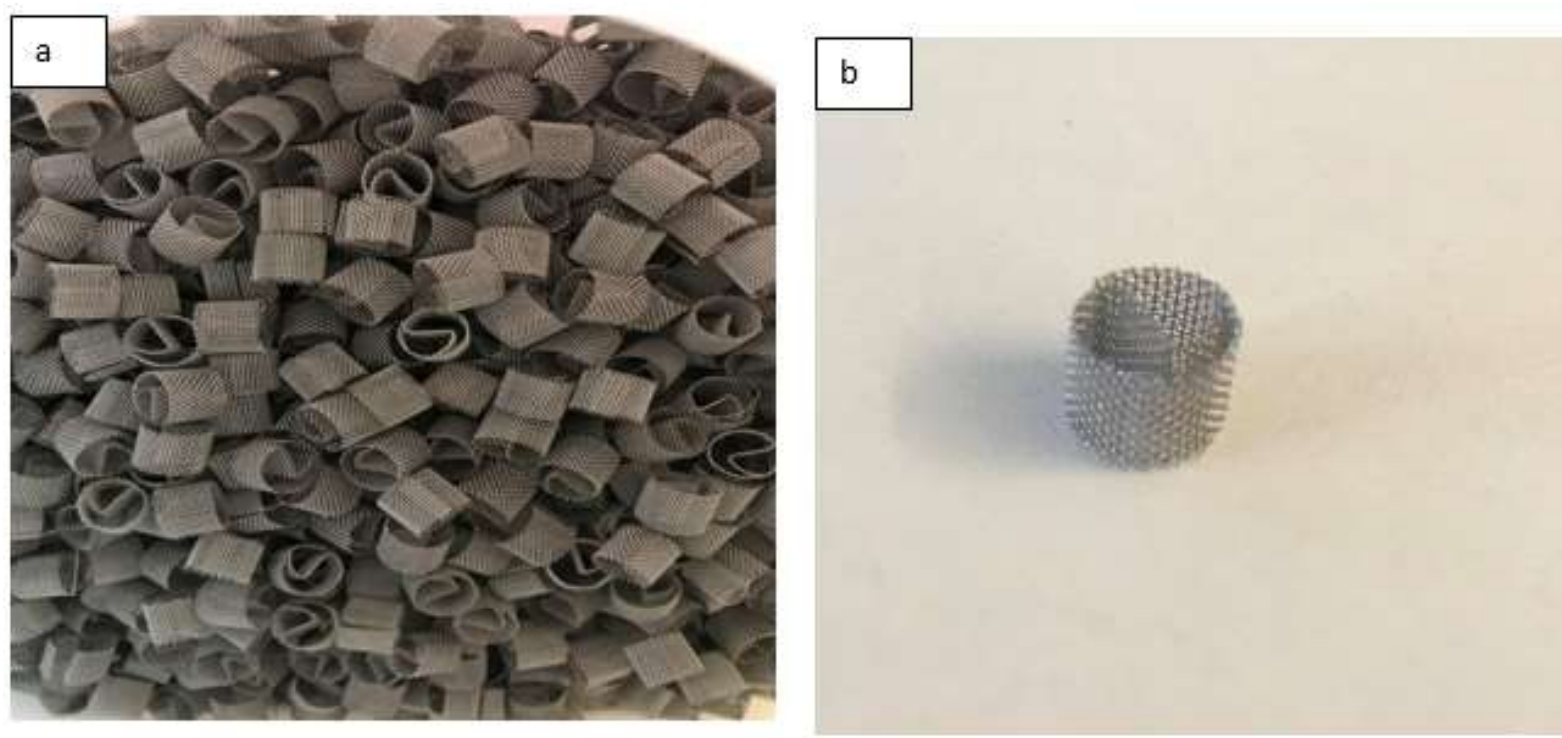

Figure 1. Stainless steel packing Dixon ring $1 / 4$ in, (a) randomly packed (b) single element, produced by Croft Filters Ltd. 


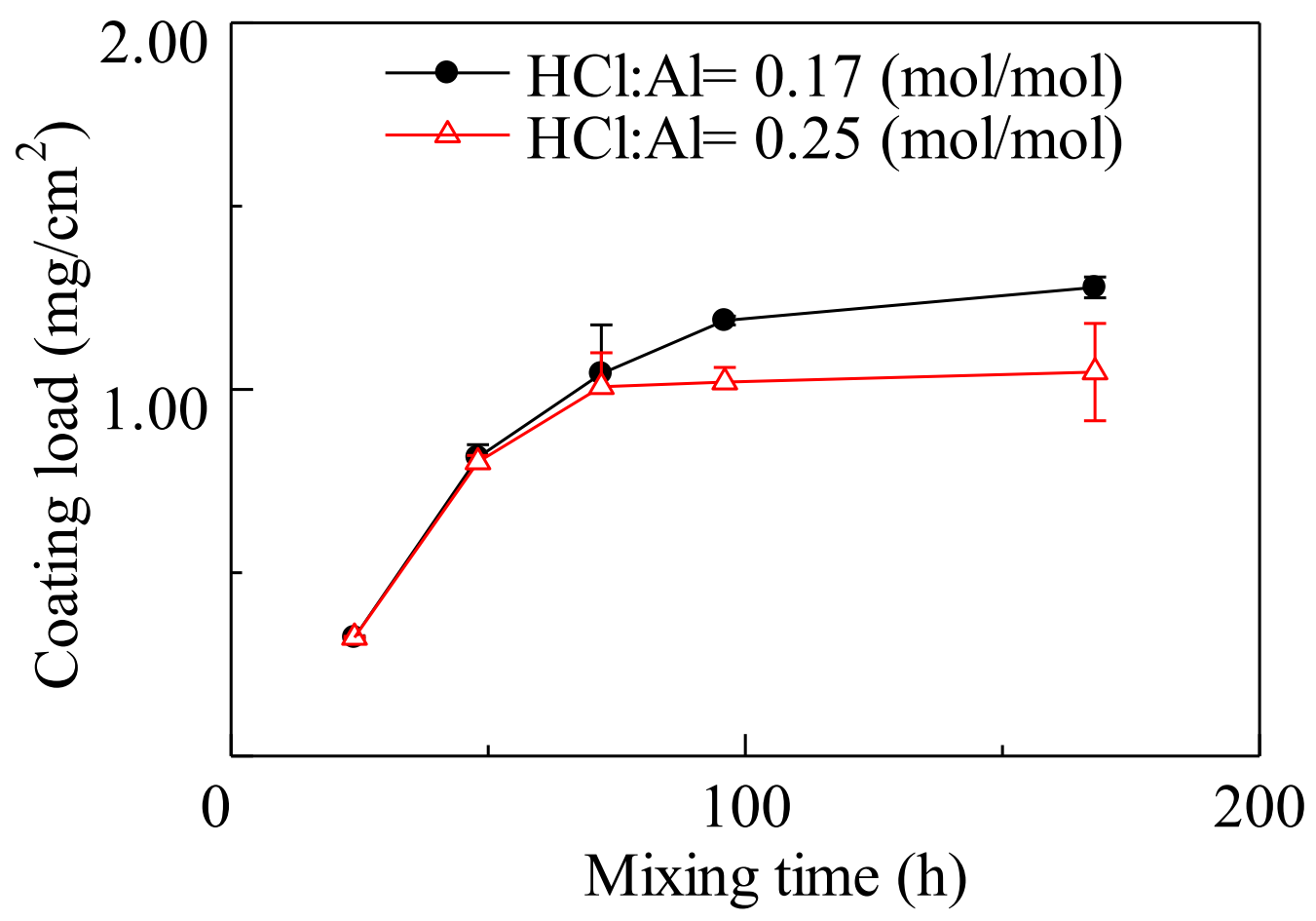

Figure 2. Effect of mixing time on the coating load for (Black circles) $\mathrm{Al} / \mathrm{HCl}=0.17$ $(\mathrm{mol} / \mathrm{mol})$ and $(\mathrm{Red}$ triangles$) \mathrm{Al} / \mathrm{HCl}=0.25(\mathrm{~mol} / \mathrm{mol})$. Coating parameters: $\mathrm{Al} / \mathrm{H}_{2} \mathrm{O}=0.01$ $(\mathrm{mol} / \mathrm{mol})$, aging time $=168 \mathrm{~h}$, calcination temperature $=773 \mathrm{~K}$. 

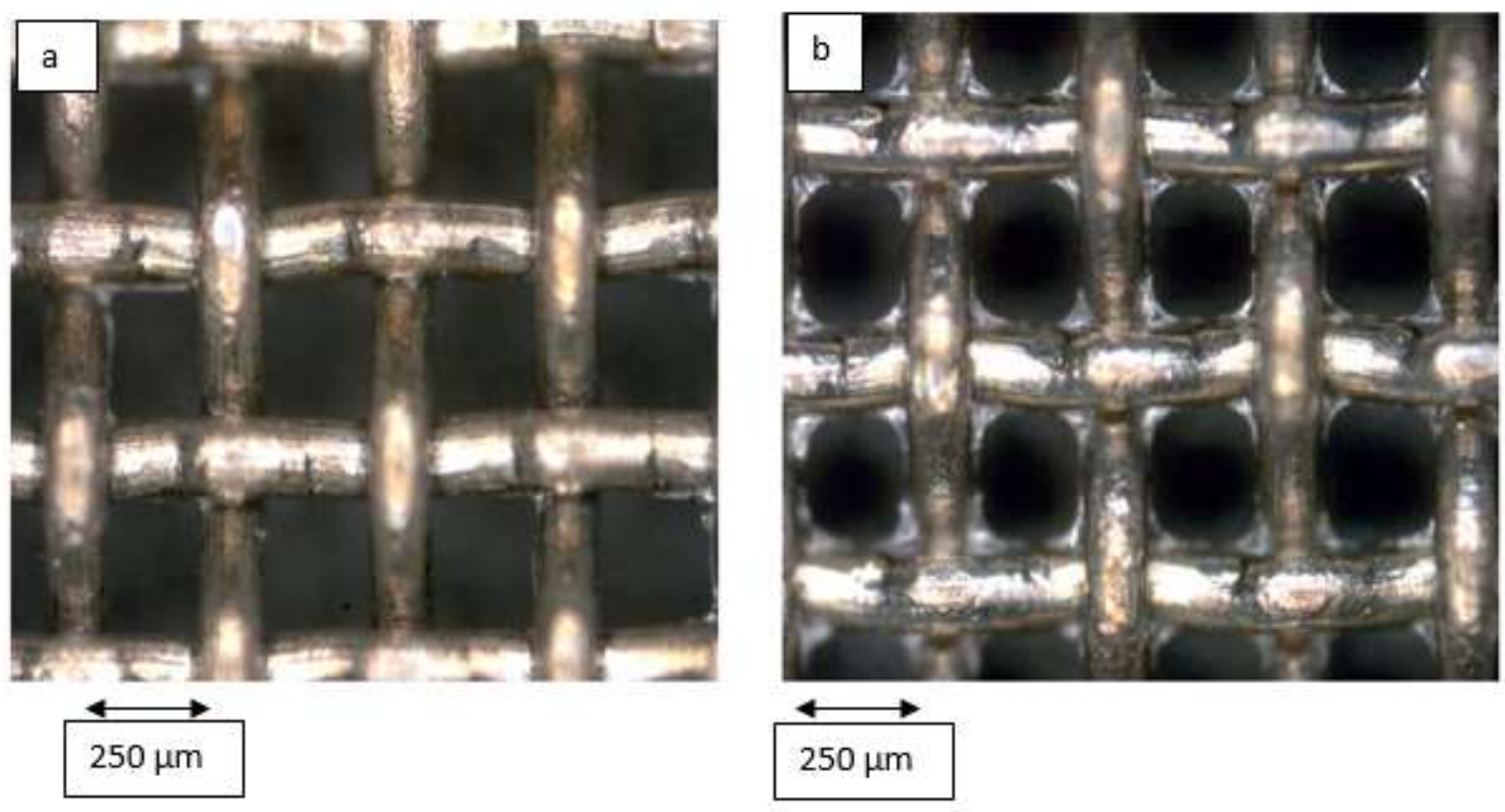

Figure 3. Optical micrograph $(10 \mathrm{X})$ of coated Dixon ring with: (a) mixing time $=24 \mathrm{~h}$ and (b) mixing time $=96 \mathrm{~h}$. Coating parameters: $\mathrm{HCl} / \mathrm{Al}=0.25(\mathrm{~mol} / \mathrm{mol}), \mathrm{Al} / \mathrm{H}_{2} \mathrm{O}=0.01$ $(\mathrm{mol} / \mathrm{mol})$, aging time $=168 \mathrm{~h}$ and calcination temperature $=773 \mathrm{~K}$. 


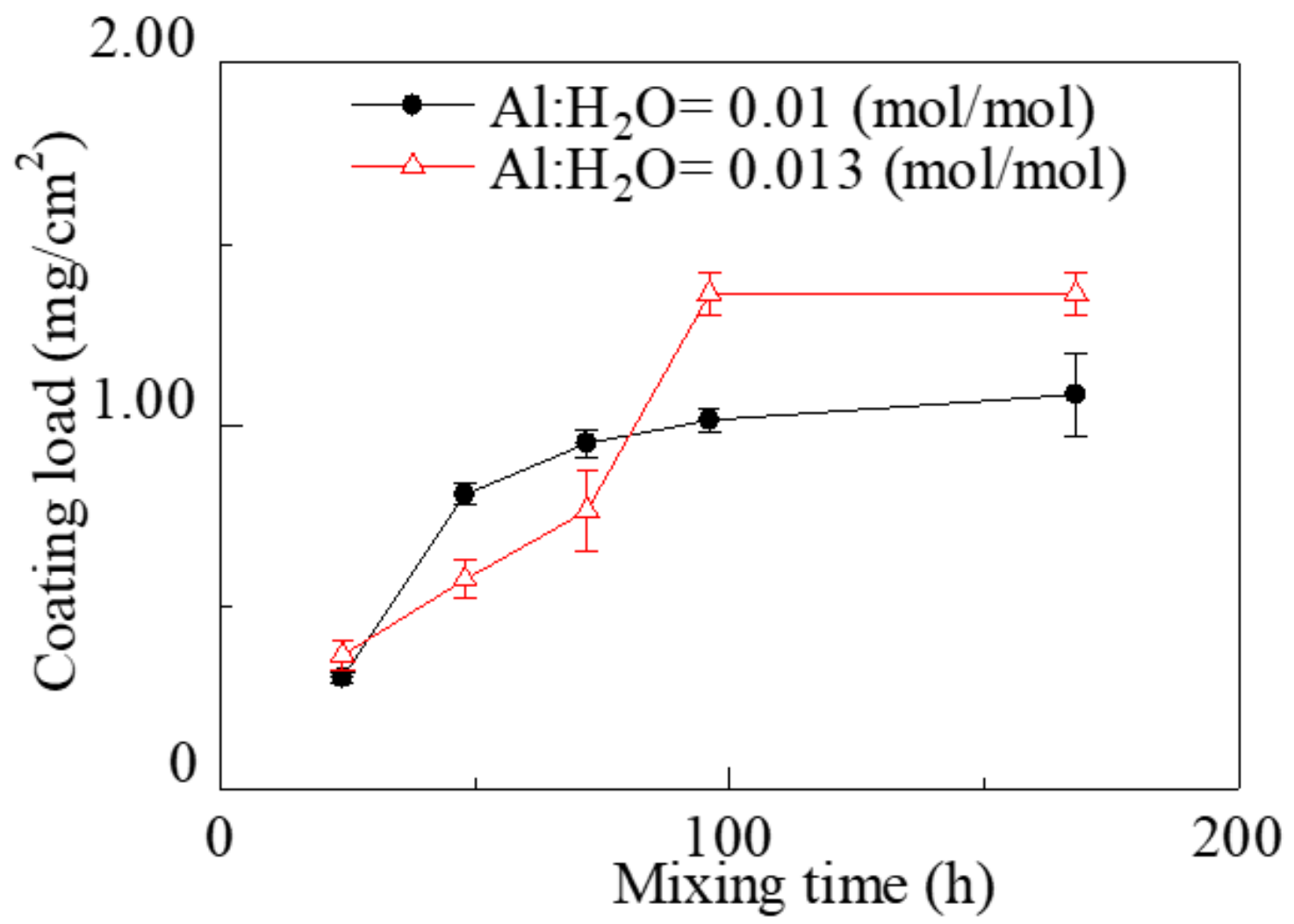

Figure 4. Effect of mixing time on the coating load for: (Black circles) $\mathrm{Al} / \mathrm{H}_{2} \mathrm{O}=0.01$ $(\mathrm{mol} / \mathrm{mol})$ and $($ Red triangles $) \mathrm{Al} / \mathrm{H}_{2} \mathrm{O}=0.013(\mathrm{~mol} / \mathrm{mol})$. Coating parameters: $\mathrm{HCl} / \mathrm{Al}=0.25$ $(\mathrm{mol} / \mathrm{mol})$ aging time $=168 \mathrm{~h}$ and calcination temperature $=773 \mathrm{~K}$. 


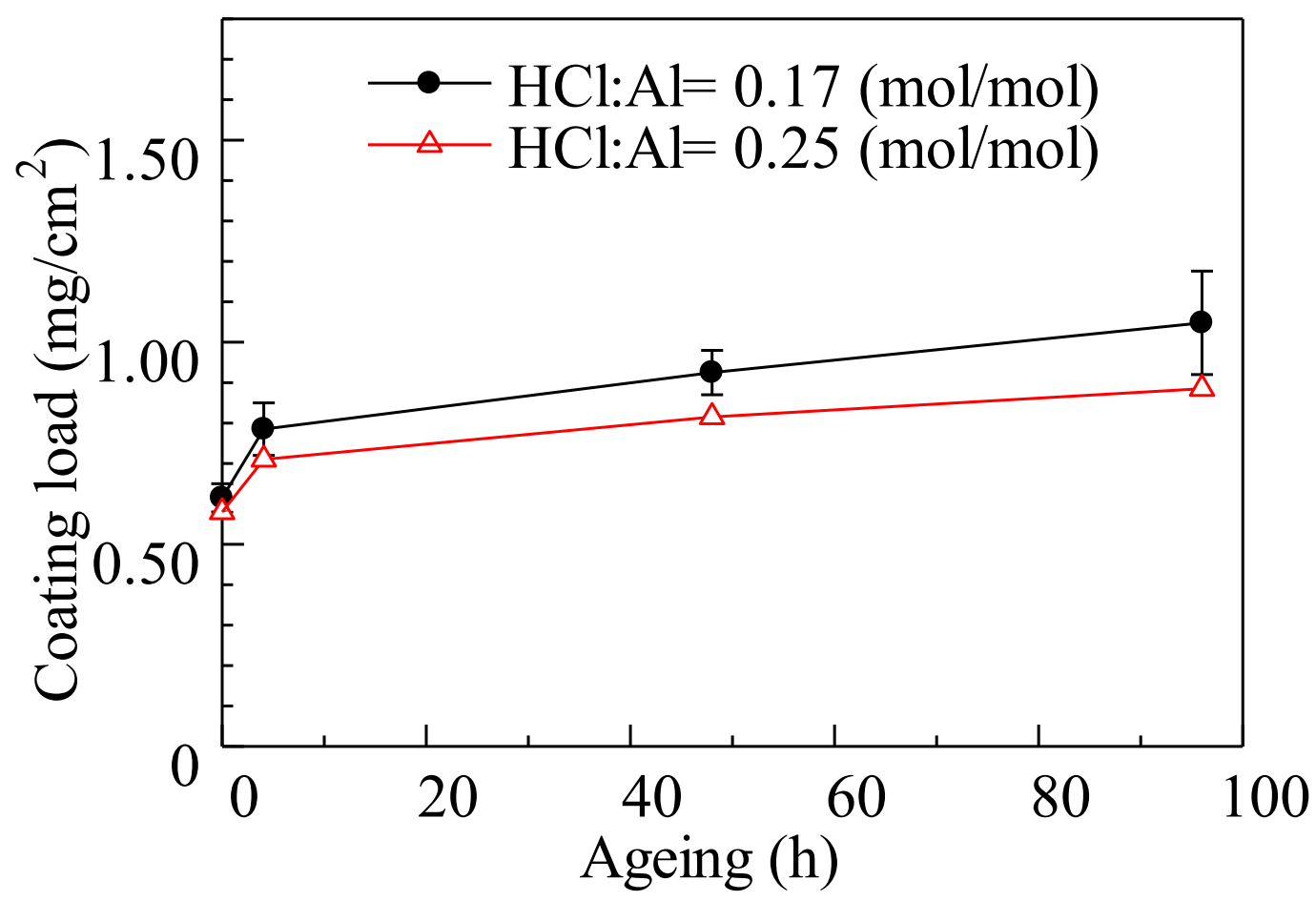

Figure 5. Effect of ageing time on the coating load for: (Black circles) $\mathrm{HCl} / \mathrm{Al}=0.17$ (mol/ mol) and (Red triangles) $\mathrm{HCl} / \mathrm{Al}=0.25(\mathrm{~mol} / \mathrm{mol})$. Coating parameters: $\mathrm{Al} / \mathrm{H}_{2} \mathrm{O}=0.01$ $(\mathrm{mol} / \mathrm{mol})$, mixing time $=93 \mathrm{~h}$ and calcination temperature $=773 \mathrm{~K}$ 


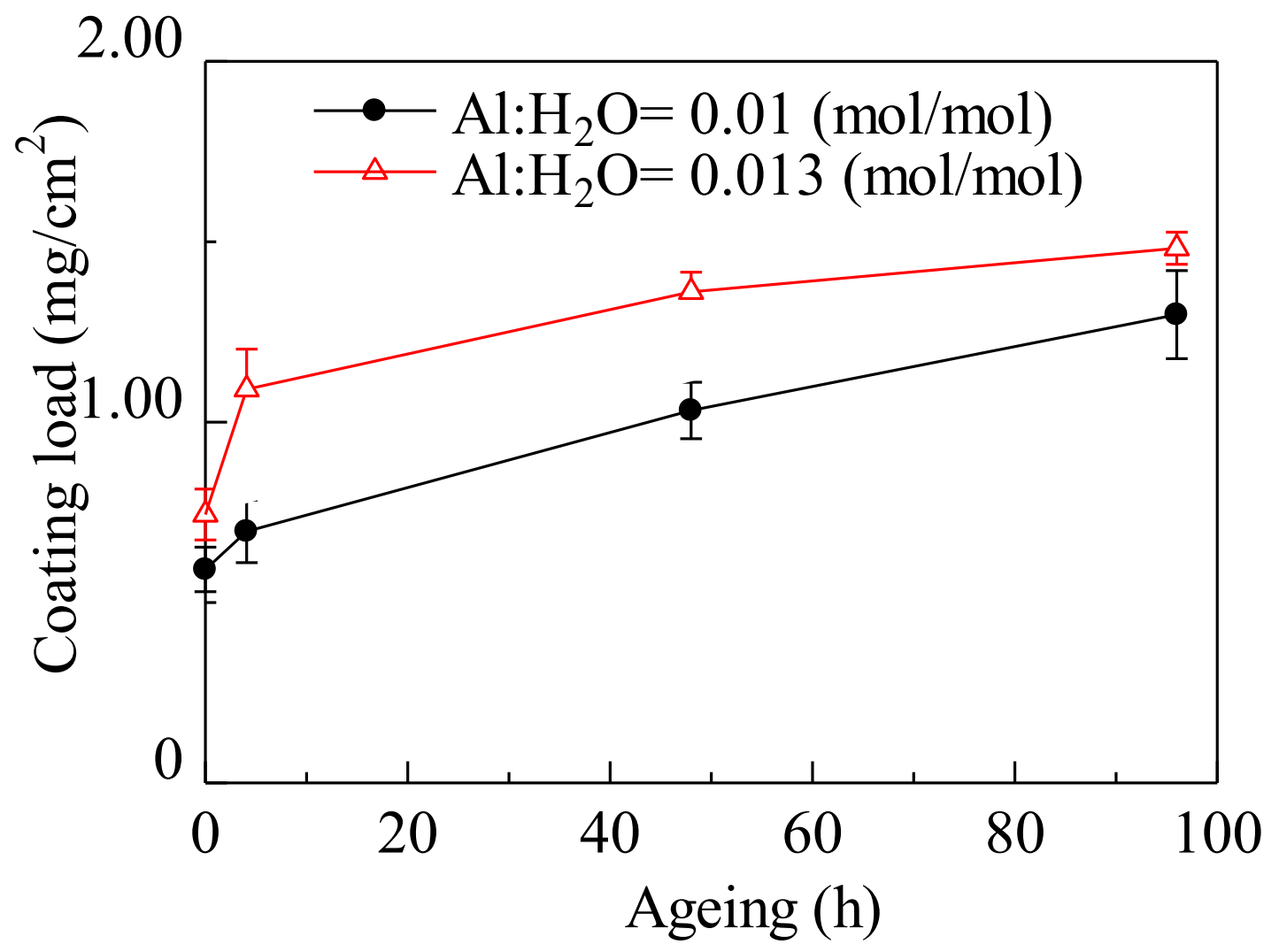

Figure 6. Effect of ageing time on the coating load for: (Black circles) $\mathrm{Al} / \mathrm{H}_{2} \mathrm{O}=0.01$ $(\mathrm{mol} / \mathrm{mol})$ and $(\mathrm{Red}$ triangles $) \mathrm{Al} / \mathrm{H}_{2} \mathrm{O}=0.013(\mathrm{~mol} / \mathrm{mol})$. Coating parameters: $\mathrm{HCl} / \mathrm{Al}=0.25$ $(\mathrm{mol} / \mathrm{mol})$ and mixing time $=96 \mathrm{~h}$ and calcination temperature $=773 \mathrm{~K}$. 


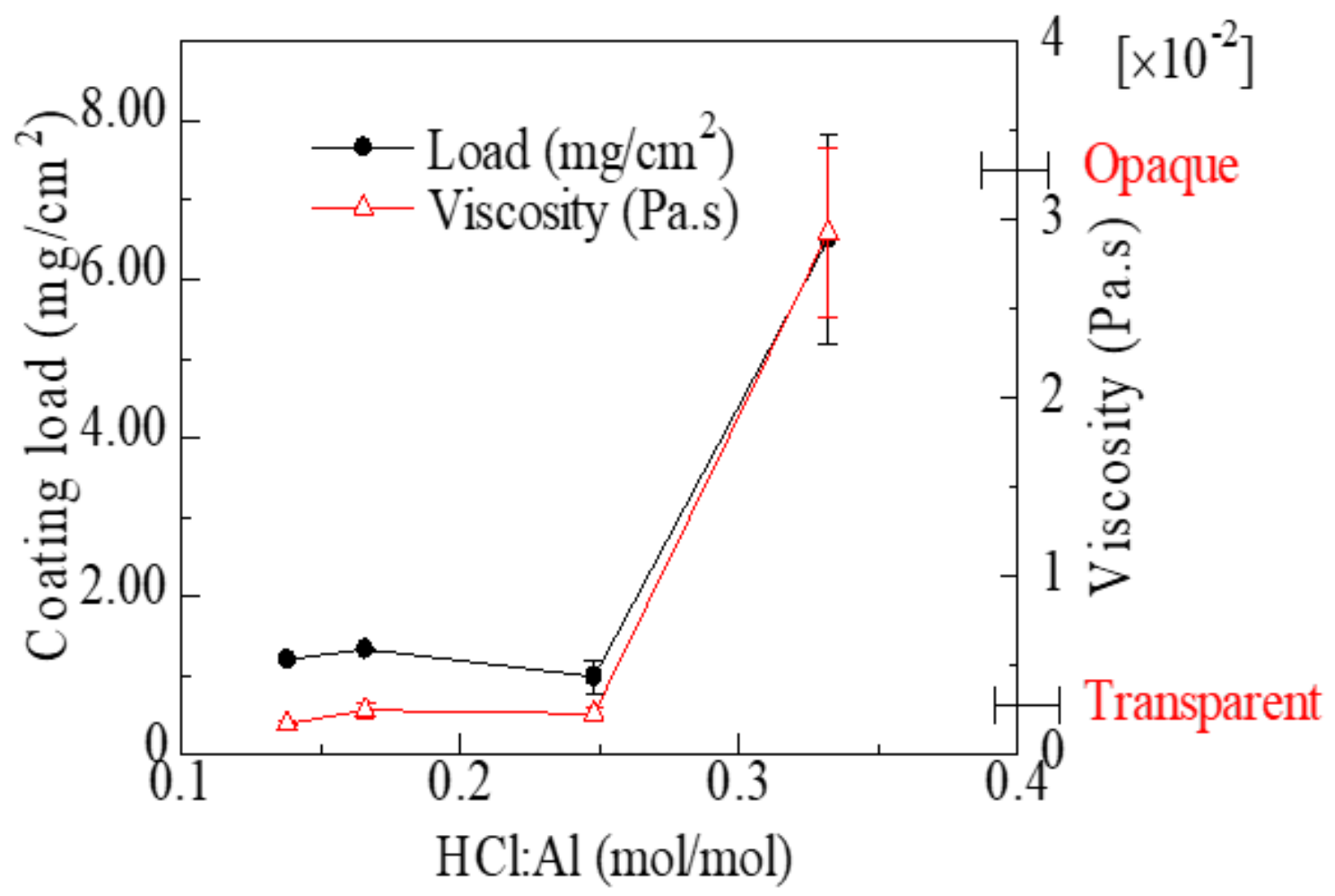

Figure 7. The influence of $\mathrm{HCl} / \mathrm{Al}$ ratio in the starting mixture on: (Black circles) Coating load and (Red Triangles) viscosity. Coating parameters: $\mathrm{Al} / \mathrm{H}_{2} \mathrm{O}=0.01(\mathrm{~mol} / \mathrm{mol})$, mixing time $=96 \mathrm{~h}$, aging time $=48 \mathrm{~h}$ and calcination temperature $=773 \mathrm{~K}$. 


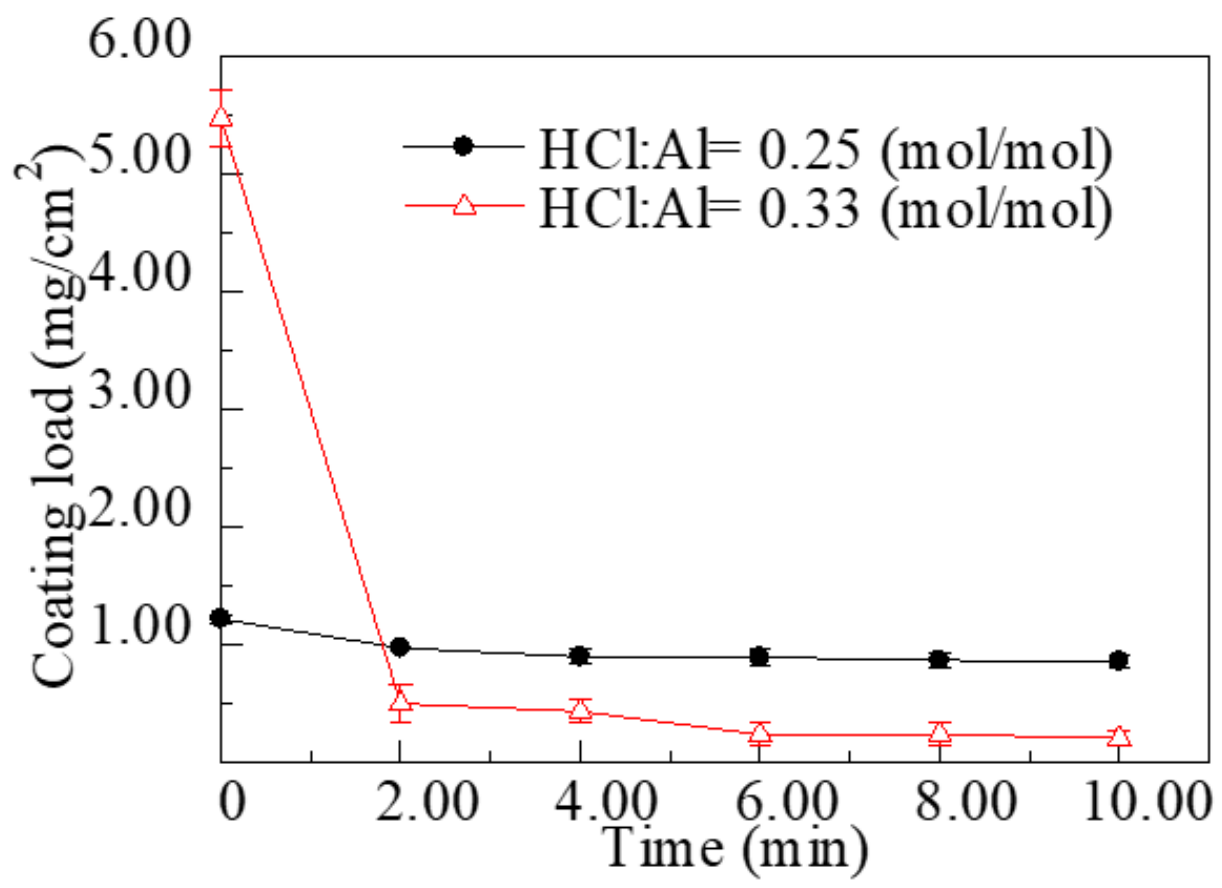

Figure 8. Ultrasonic adhesiveness test - influence of ultrasound bath time on the coating load for: $($ Black circles) $\mathrm{HCl} / \mathrm{Al}=0.25(\mathrm{~mol} / \mathrm{mol})$ and $($ Red triangles $) \mathrm{HCl} / \mathrm{Al}=0.33(\mathrm{~mol} / \mathrm{mol})$. Coating parameters: $\mathrm{Al} / \mathrm{H}_{2} \mathrm{O}=0.01(\mathrm{~mol} / \mathrm{mol})$, mixing time $=96 \mathrm{~h}$, aging time $=48 \mathrm{~h}$ and calcination temperature $=773 \mathrm{~K}$. 


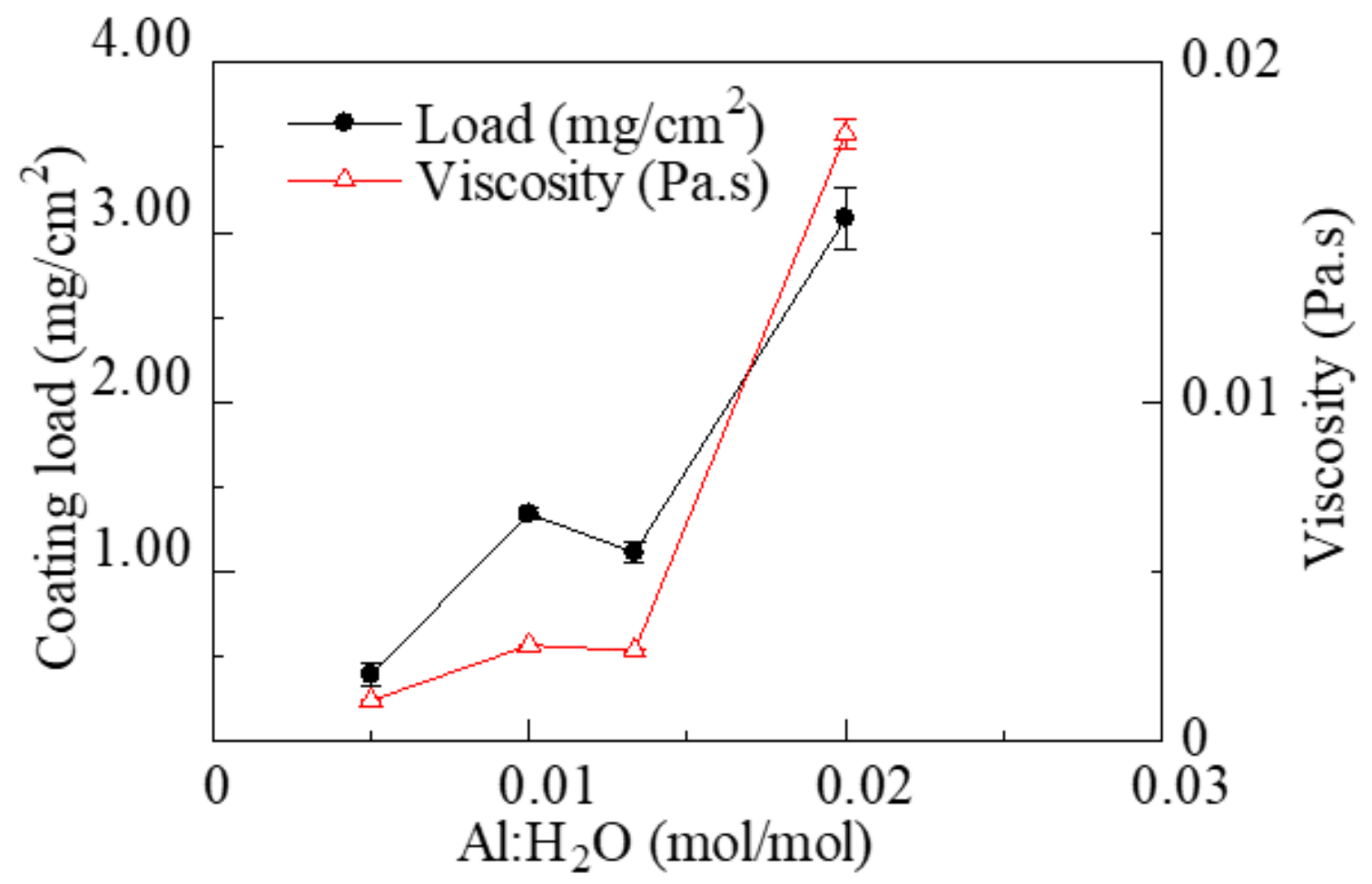

Figure 9. Influence of $\mathrm{Al} / \mathrm{H}_{2} \mathrm{O}$ ratio in the starting mixture on: (Black circles) coating load and (Red Triangles) viscosity. Coating parameters: $\mathrm{HCl} / \mathrm{Al}=0.021(\mathrm{~mol} / \mathrm{mol})$, mixing time $=$ $96 \mathrm{~h}$, aging time $=48 \mathrm{~h}$ and calcination temperature $=773 \mathrm{~K}$. 


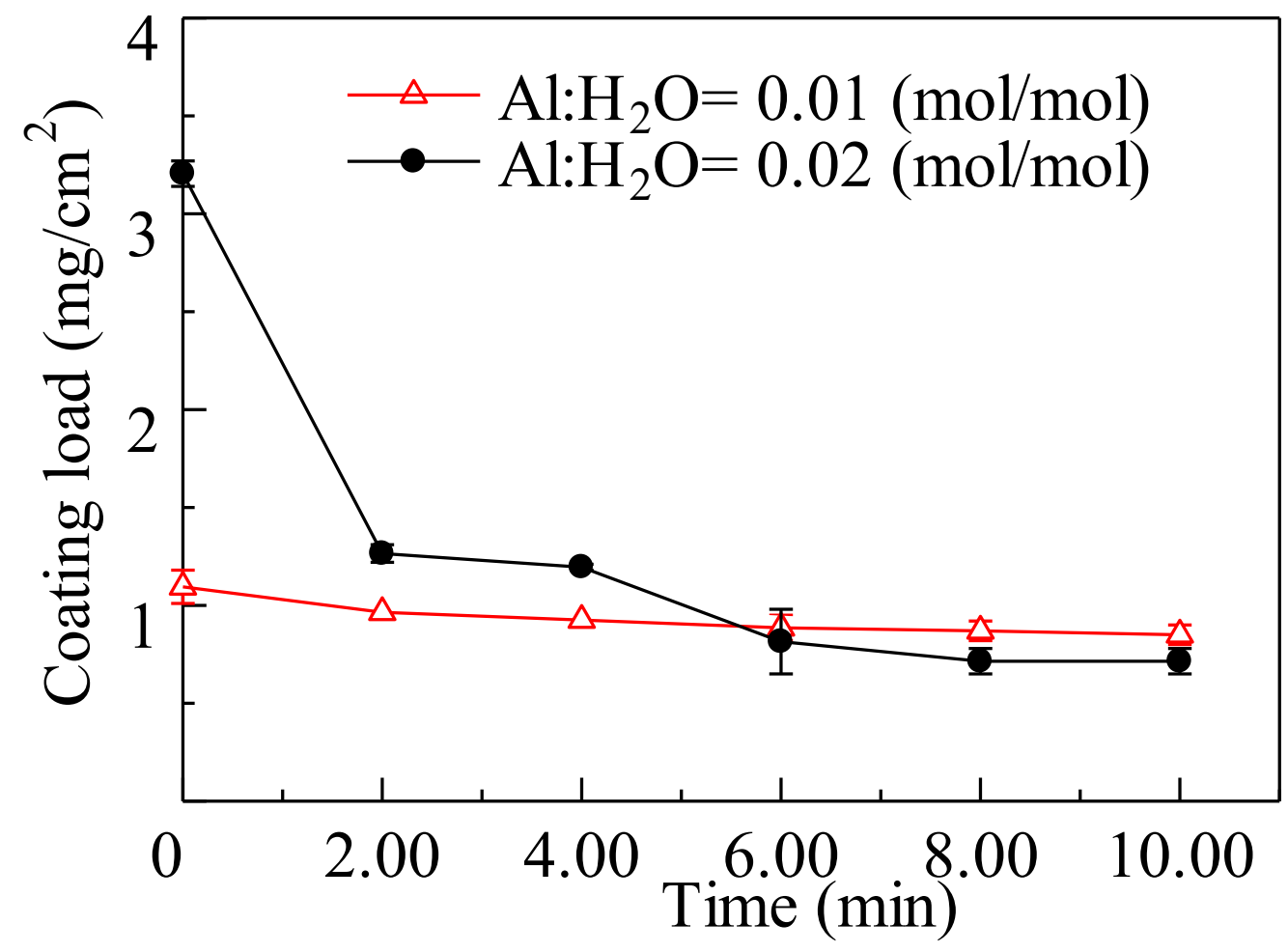

Figure 10. Ultrasonic adhesiveness test - influence of ultrasound bath time on the coating load for: (Black circles) $\mathrm{Al} / \mathrm{H}_{2} \mathrm{O}=0.02$ (mol $/ \mathrm{mol}$ ) and (Red triangles) $\mathrm{Al} / \mathrm{H}_{2} \mathrm{O}=0.01$ $(\mathrm{mol} / \mathrm{mol})$. Coating parameters: $\mathrm{HCl} / \mathrm{Al}=0.25(\mathrm{~mol} / \mathrm{mol})$, mixing time $=96 \mathrm{~h}$, aging time $=$ $48 \mathrm{~h}$ and calcination temperature $=773 \mathrm{~K}$. 


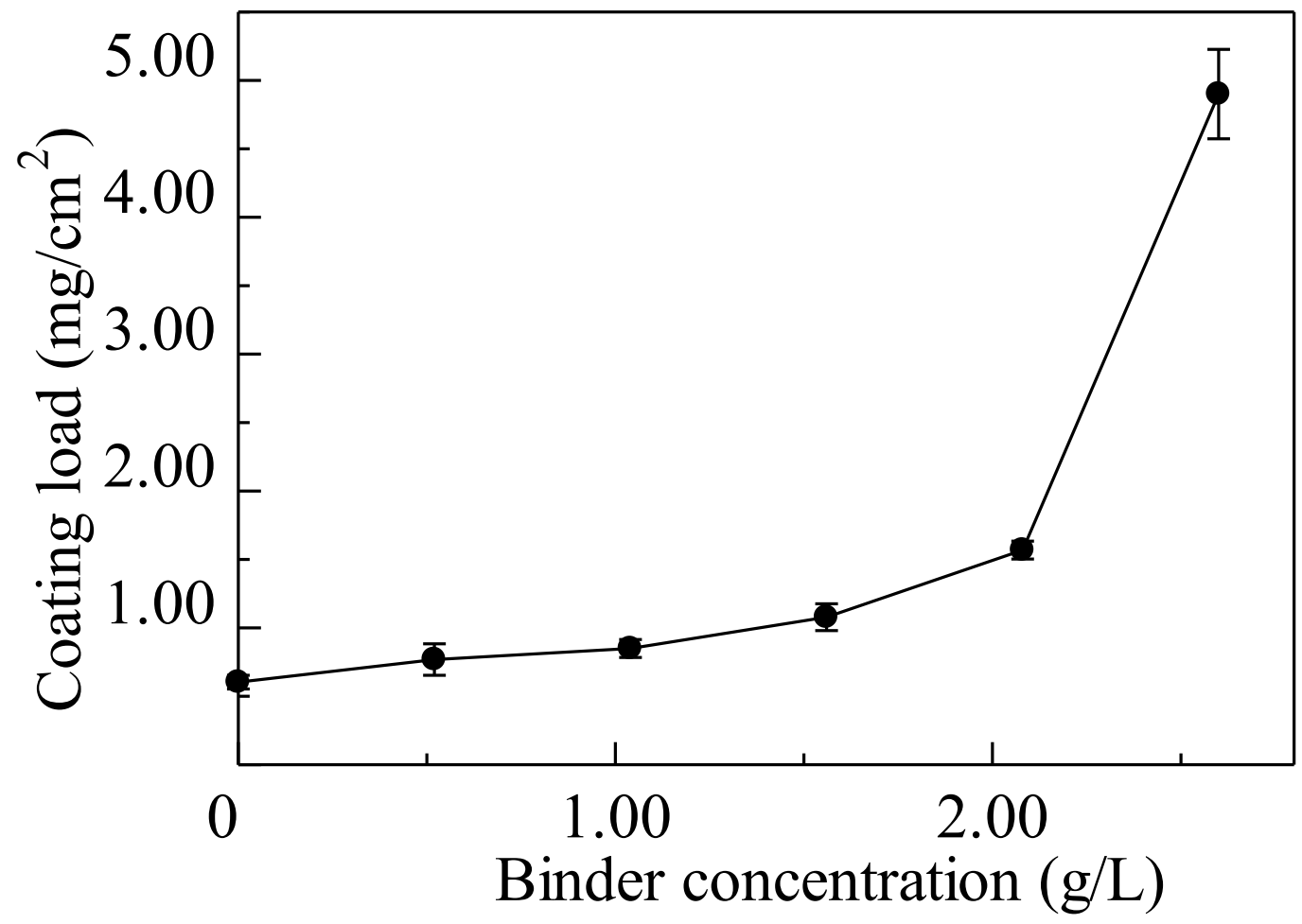

Figure 11. Effect of binder concentration on the coating load. Coating parameters: $\mathrm{Al} / \mathrm{H}_{2} \mathrm{O}=$ $0.01(\mathrm{~mol} / \mathrm{mol}), \mathrm{HCl} / \mathrm{Al}=0.25(\mathrm{~mol} / \mathrm{mol})$, mixing time $=96 \mathrm{~h}$, ageing time $=48 \mathrm{~h}$ and calcination temperature $=773 \mathrm{~K}$. 

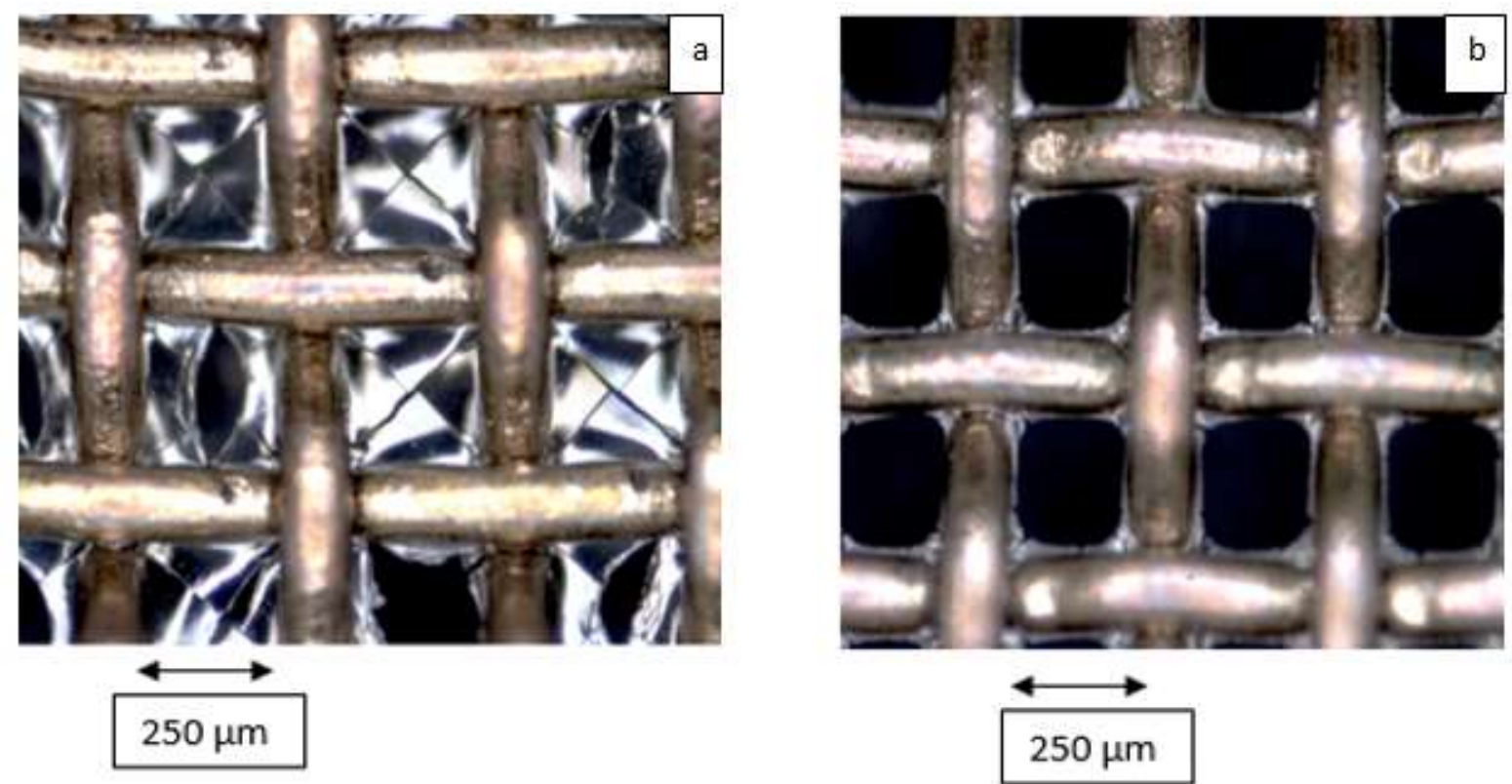

Figure 12. Optical micrograph (10X) of coated Dixon ring with using PEI concentration of: (a) $2.6 \mathrm{~g} / \mathrm{L}$ and (b) $2.08 \mathrm{~g} / \mathrm{L}$. Coating parameters: $\mathrm{HCl} / \mathrm{Al}=0.25(\mathrm{~mol} / \mathrm{mol}), \mathrm{Al} / \mathrm{H}_{2} \mathrm{O}=0.01$ $(\mathrm{mol} / \mathrm{mol})$, mixing time $=96 \mathrm{~h}$, aging time $=48 \mathrm{~h}$ and calcination temperature $=773 \mathrm{~K}$. 


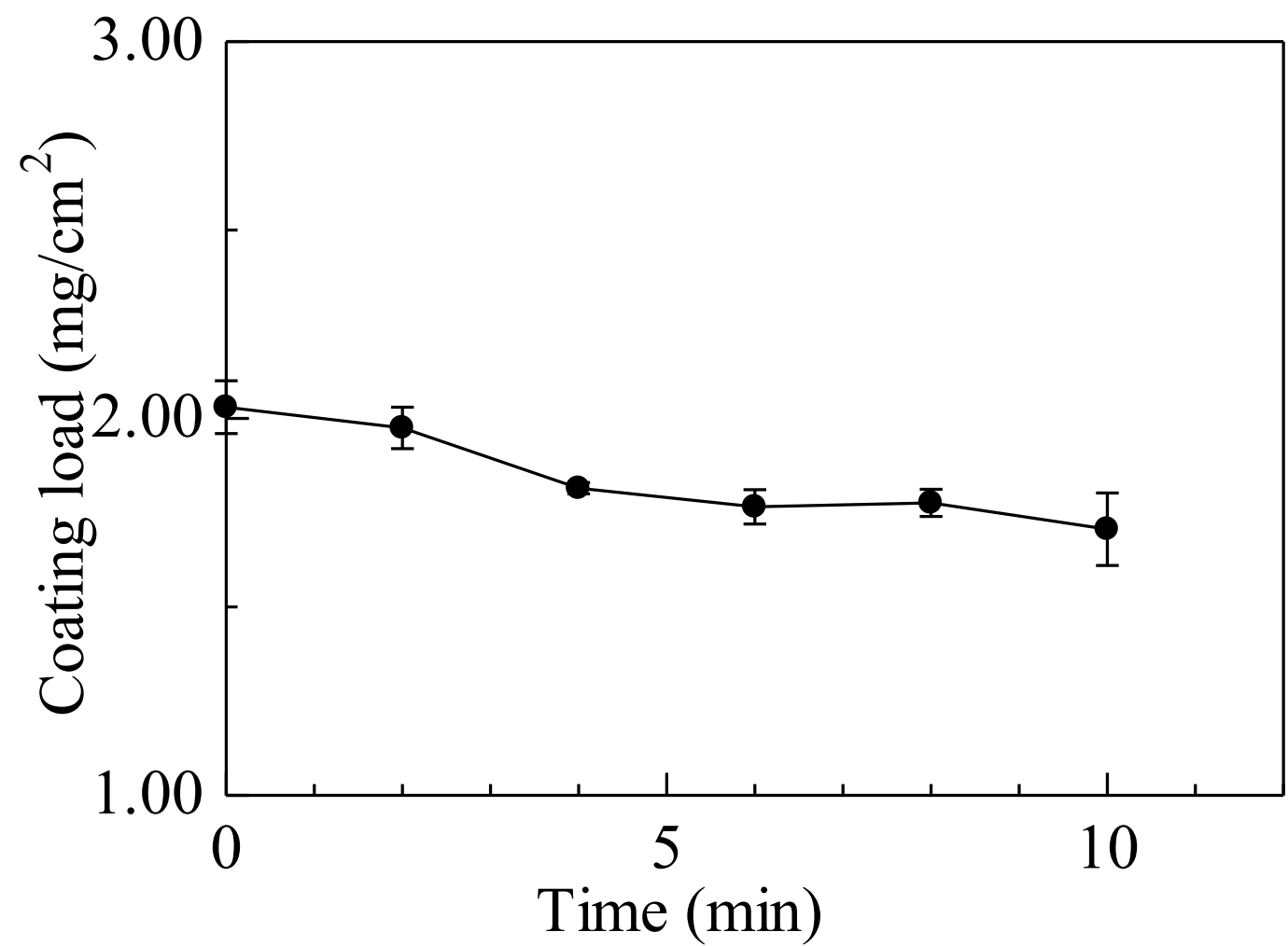

Figure 13. The coating adhesion in ultrasound bath tests with the addition of PEI concentration $=2.1(\mathrm{~g} / \mathrm{L})$. Coating parameters: $\mathrm{Al} / \mathrm{H}_{2} \mathrm{O}=0.01(\mathrm{~mol} / \mathrm{mol}), \mathrm{HCl} / \mathrm{Al}=0.25$ $(\mathrm{mol} / \mathrm{mol})$, mixing time $=96 \mathrm{~h}$, ageing time $=48 \mathrm{~h}$ and calcination temperature $=773 \mathrm{~K}$. 


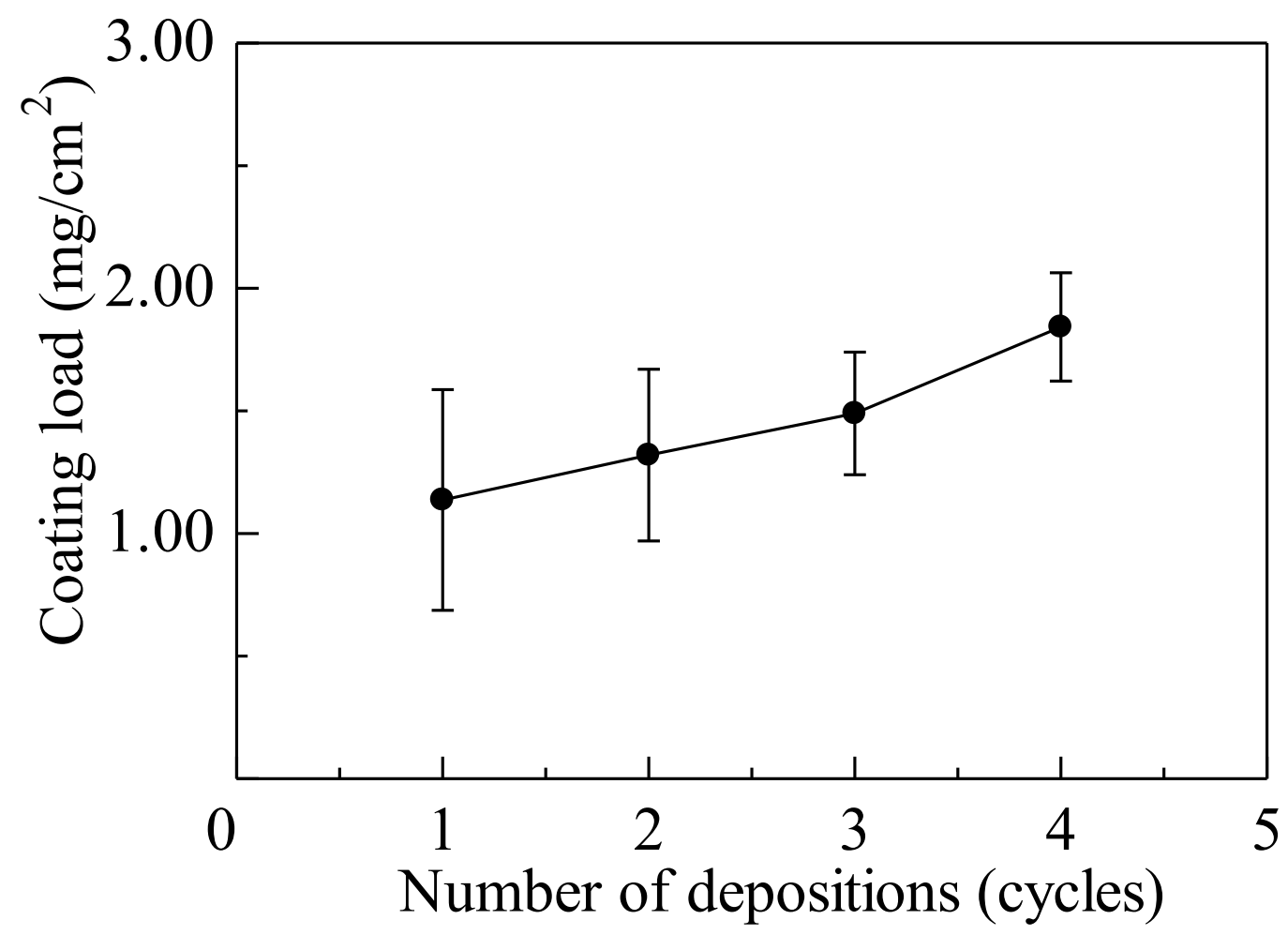

Figure 14. Coating load vs deposition cycles for Dixon rings. Coating parameters: $\mathrm{Al} / \mathrm{H}_{2} \mathrm{O}=$ $0.01(\mathrm{~mol} / \mathrm{mol}), \mathrm{HCl} / \mathrm{Al}=0.25(\mathrm{~mol} / \mathrm{mol})$, mixing time $=96 \mathrm{~h}$, ageing time $=48 \mathrm{~h}$ and calcination temperature $=773 \mathrm{~K}$. 

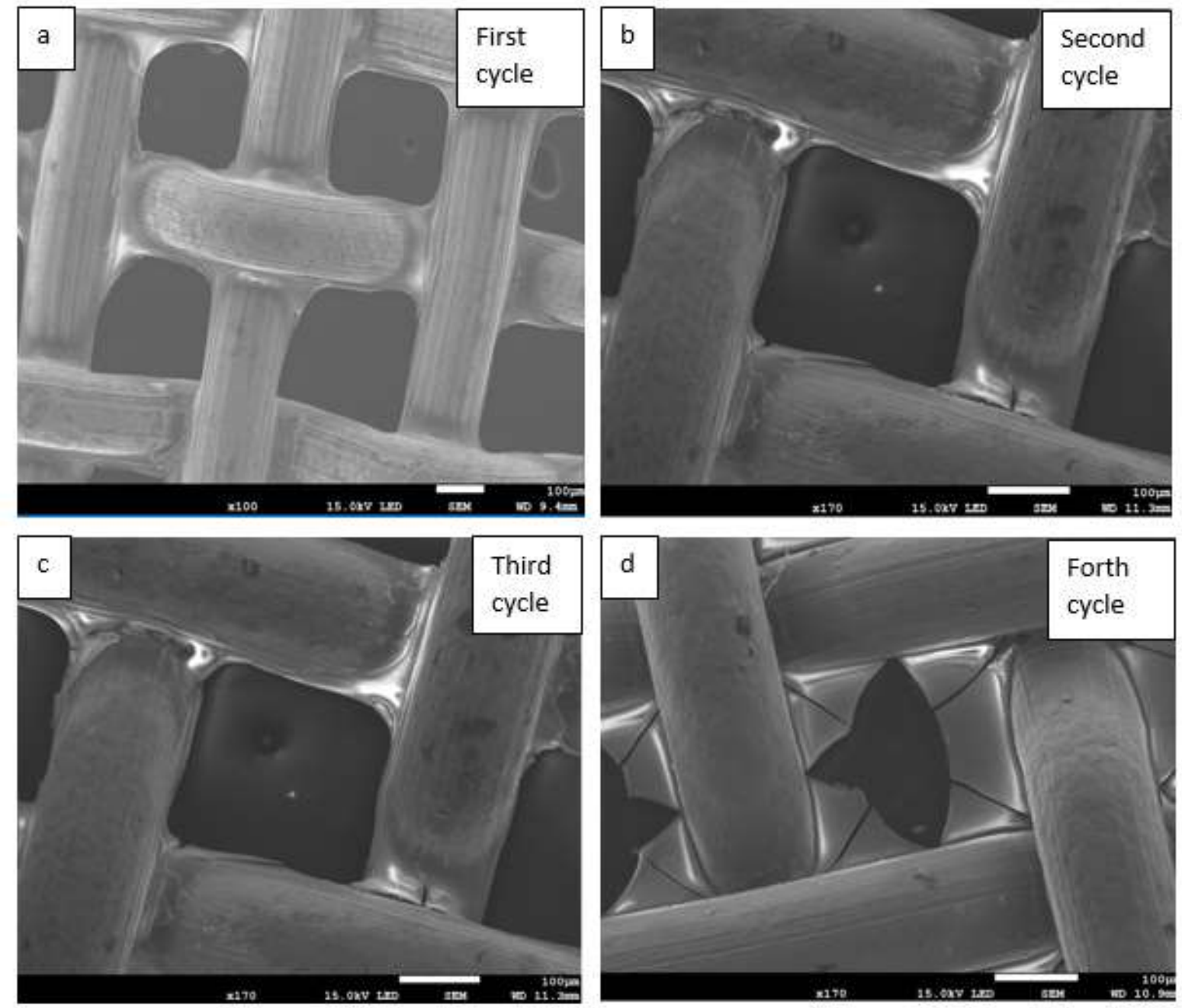

Figure 15. Coupled SEM-EDS results on Dixon ring coated with: (a) one, (b) two, c) three, and d) four deposition cycles. Coating parameters: $\mathrm{Al} / \mathrm{H}_{2} \mathrm{O}=0.01(\mathrm{~mol} / \mathrm{mol}), \mathrm{HCl} / \mathrm{Al}=0.25$ $(\mathrm{mol} / \mathrm{mol})$, mixing time $=96 \mathrm{~h}$, ageing time $=48 \mathrm{~h}$ and calcination temperature $=773 \mathrm{~K}$. 


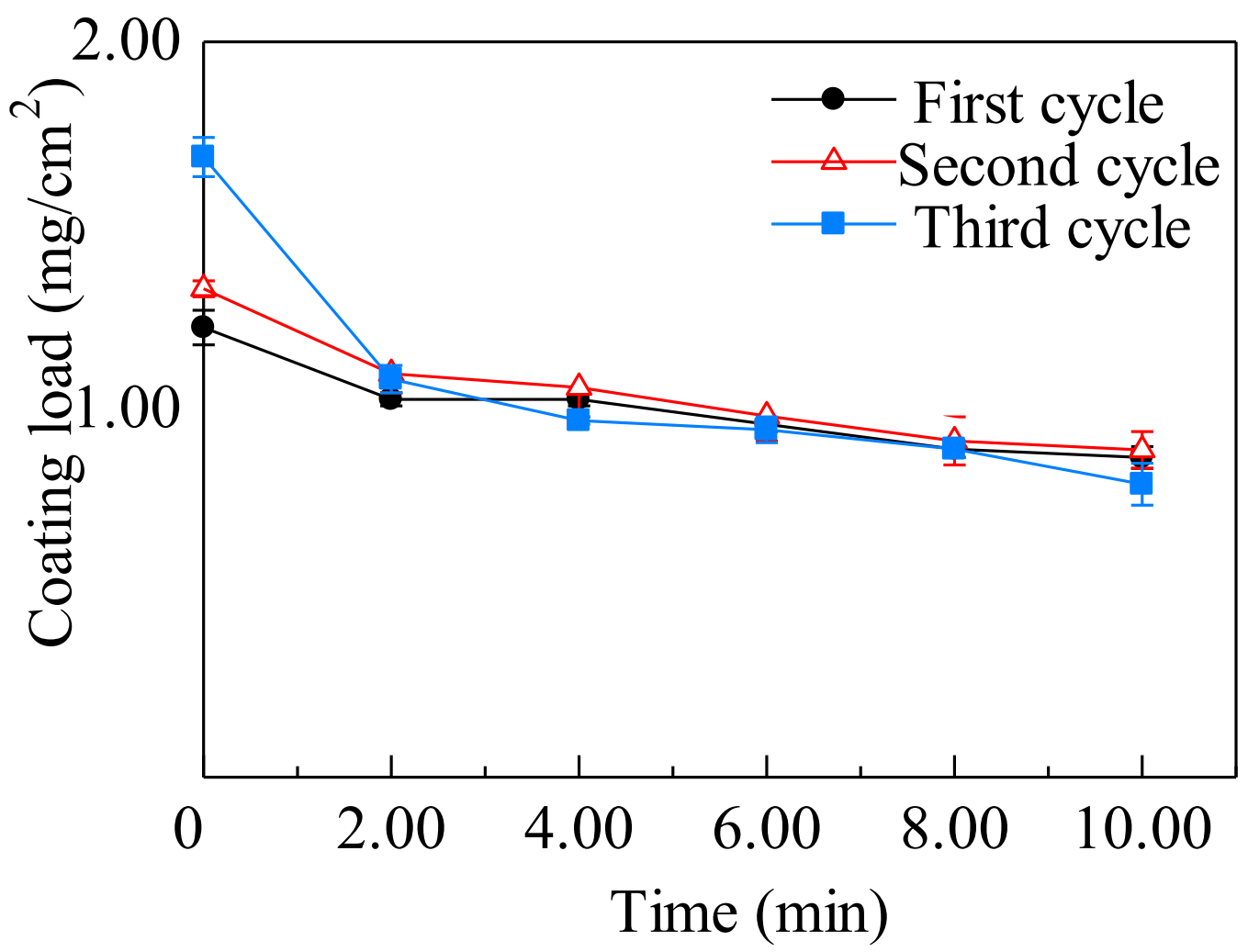

Figure 16. The coating adhesion in ultrasound bath tests for multiple depositions (Black circles) first cycle, (Red triangles) second cycle and (Blue squares) third cycle. Coating parameters: $\mathrm{Al} / \mathrm{H}_{2} \mathrm{O}=0.01(\mathrm{~mol} / \mathrm{mol}), \mathrm{HCl} / \mathrm{Al}=0.25(\mathrm{~mol} / \mathrm{mol})$, mixing time $=96 \mathrm{~h}$, ageing time $=48 \mathrm{~h}$ and calcination temperature $=773 \mathrm{~K}$. 


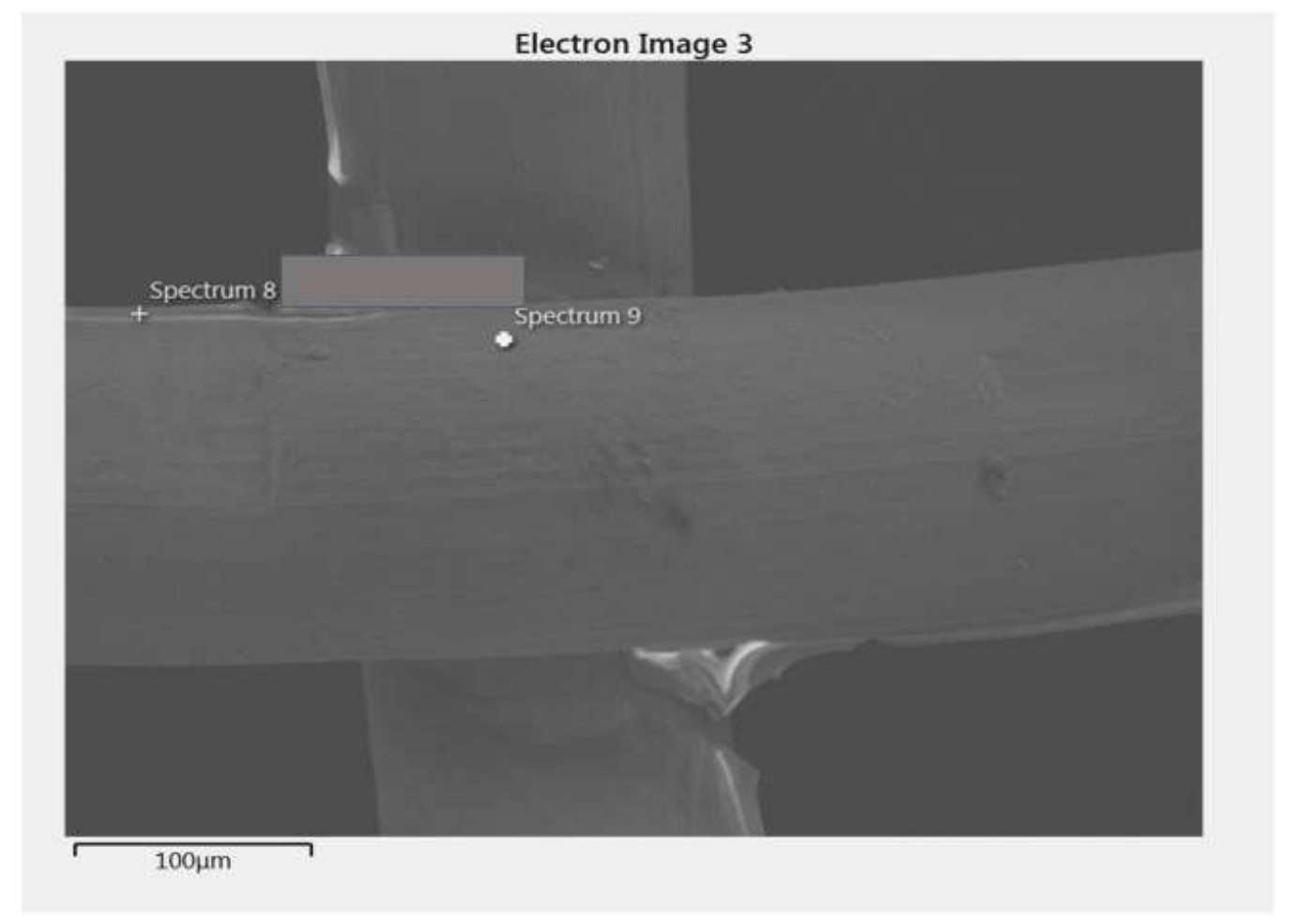

Figure 17. SEM-image of a coated Dixon ring, coating parameters: $\mathrm{Al} / \mathrm{H}_{2} \mathrm{O}=0.01$ $(\mathrm{mol} / \mathrm{mol}), \mathrm{HCl} / \mathrm{Al}=0.25(\mathrm{~mol} / \mathrm{mol})$, mixing time $=96 \mathrm{~h}$, ageing time $=48 \mathrm{~h}$ and calcination temperature $=773 \mathrm{~K}$. 

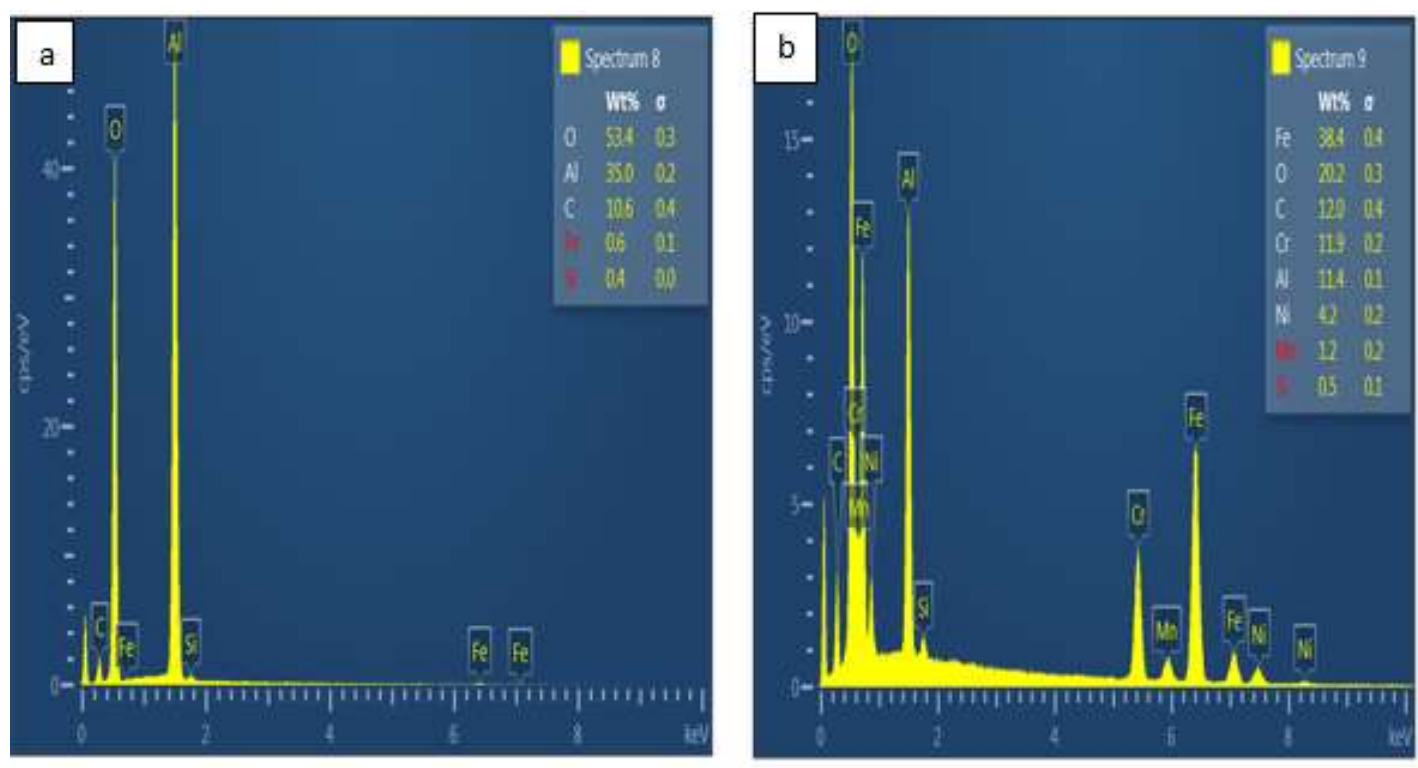

Figure 18. The EDS spectrum for the local points (a) 8 and (b) 9 for the sample in Figure 17. 

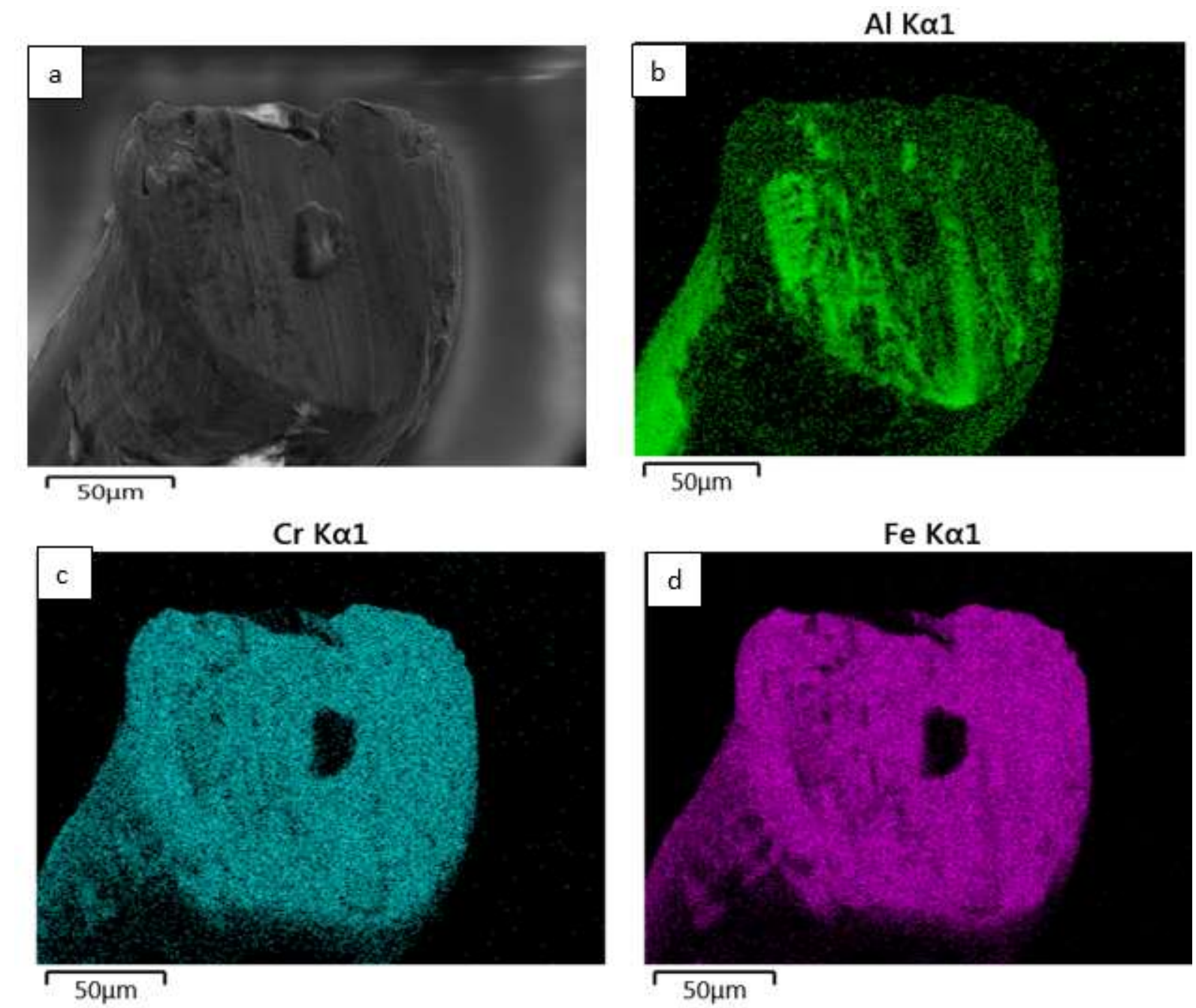

Figure 19. SEM image of the wire after the cut (a), coupled SEM-EDS mapping (b) $\mathrm{Al}$ (c) $\mathrm{Cr}$ (d) Fe results for a cut through a coated Dixon ring. Coating parameters: $\mathrm{HCl} / \mathrm{Al}=0.25$ (mol $/ \mathrm{mol}), \mathrm{Al} / \mathrm{H}_{2} \mathrm{O}=0.01(\mathrm{~mol} / \mathrm{mol})$, mixing time $=96 \mathrm{~h}$, ageing time $=48 \mathrm{~h}$ and calcination temperature $=773 \mathrm{~K}$. 

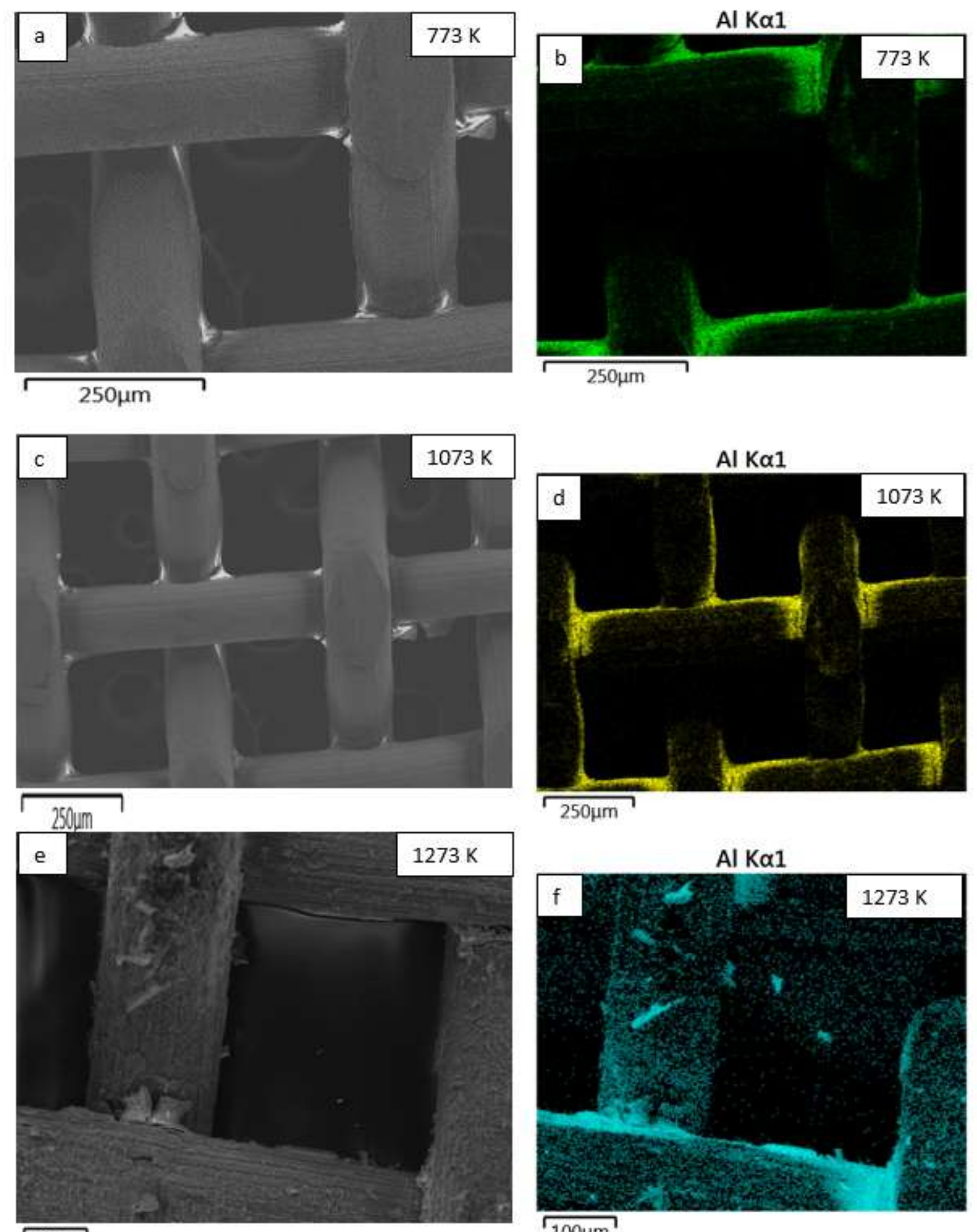

$\sqrt{100 \mu \mathrm{m}}$

$\widehat{100 \mu \mathrm{m}}$

Figure 20. SEM images (a, $c$ and e) and EDS images of Al distribution (b, $d$ and $f$ ) of calcined coating. Calcination temperature: (a, b) at $773 \mathrm{~K},(\mathrm{c}, \mathrm{d})$ at $1073 \mathrm{~K}$ and (e, f) at 1273 K. Coating parameters: $\mathrm{Al} / \mathrm{H}_{2} \mathrm{O}=0.01(\mathrm{~mol} / \mathrm{mol}), \mathrm{HCl} / \mathrm{Al}=0.25(\mathrm{~mol} / \mathrm{mol})$, mixing time $=$ $96 \mathrm{~h}$ and ageing time $=48 \mathrm{~h}$. 